\title{
Corruption perceptions vs. corruption reality
}

\author{
Benjamin A. Olken
}

MIT, United States

NBER, United States

\section{A R T I C L E I N F O}

\section{Article history:}

Received 10 April 2007

Received in revised form 11 March 2009

Accepted 11 March 2009

Available online 26 March 2009

\section{Keywords:}

Corruption

Perceptions

Beliefs

\begin{abstract}
A B S T R A C T
This paper examines the accuracy of corruption perceptions by comparing Indonesian villagers' reported perceptions about corruption in a road-building project in their village with a more objective measure of 'missing expenditures' in the project. I find that villagers' reported perceptions do contain real information, and that villagers are sophisticated enough to distinguish between corruption in a particular road project and general corruption in the village. The magnitude of the reported information, however, is small, in part because officials hide corruption where it is hardest for villagers to detect. I also find that there are biases in reported perceptions. The findings illustrate the limitations of relying solely on corruption perceptions, whether in designing anti-corruption policies or in conducting empirical research on corruption.
\end{abstract}

(c) 2009 Elsevier B.V. All rights reserved.

\section{Introduction}

Corruption is thought to be a significant problem in much of the developing world. Corruption not only imposes a tax on public services and private sector activity; it also creates potentially severe efficiency consequences as well (Krueger, 1974; Shleifer and Vishny, 1993; Bertrand et al., 2006). Yet despite the importance of the problem, eliminating corruption has proved difficult in all but a few developing countries.

One potential reason why corruption is so persistent is that citizens may not have accurate information about corruption. After all, since corruption is illegal, regularly and directly observing corrupt activity is almost always impossible. If citizens have accurate information about corruption, then the democratic process and grass-roots monitoring can potentially provide incentives for politicians to limit corruption. If, on the other hand, citizens have little in the way of accurate information about corrupt activity - or even if citizens know about average levels of corruption but do not know who is corrupt and who is honest - then the political process may not provide sufficient incentives to restrain corruption.

The accuracy of corruption perceptions is also important because of their ubiquitous use by international institutions and academics to measure corrupt activity. For example, corruption perceptions form

\footnotetext{
is I wish to thank Abhijit Banerjee, Esther Duflo, Amy Finkelstein, Ray Fisman, Seema Jayachandran, Larry Katz, Aart Kraay, Michael Kremer, Thomas Piketty, Susan RoseAckerman, Monica Singhal, and an anonymous referee for helpful comments. Special thanks are due to Victor Bottini, Richard Gnagey, Susan Wong, and especially Scott Guggenheim for their support and assistance throughout the project. The field work and engineering survey would have been impossible without the dedication of Faray Muhammad and Suroso Yoso Oetomo, as well as the entire P4 field staff. This project was supported by a grant from the DflD-World Bank Strategic Poverty Partnership Trust Fund. All views expressed are those of the author, and do not necessarily reflect the opinions of DfID or the World Bank.

E-mail address: bolken@mit.edu.
}

the basis of the much-cited cross-country Transparency International Corruption Index (Lambsdorff, 2003) and World Bank Governance Indicators (Kaufmann et al., 2005), and are used extensively within countries as well to assess governance at the sub-national level. Perceptions have also been widely used in academic research on the determinants of corruption. ${ }^{1}$ Measuring perceptions about corruption rather than corruption itself skirts the inherent difficulties involved in measuring corruption directly, but raises the question of how those being surveyed form their perceptions in the first place, and how accurate those reported perceptions actually are.

This paper examines the empirical relationship between reported corruption perceptions and a more objective measure of corruption, in the context of a road-building program in rural Indonesia. To construct an objective measure of corruption, I assembled a team of engineers and surveyors who, after the roads built by the project were completed, dug core samples in each road to estimate the quantity of materials used, surveyed local suppliers to estimate prices, and interviewed villagers to determine the wages paid on the project. From these data, I construct an independent estimate of the amount each road actually cost to build, and then compare this estimate to what the village reported it spent on the project on a line-item by line-item basis. The difference between what the village claimed the road cost to build and what the engineers estimated it actually cost to build forms my objective measure of corruption, which I label 'missing expenditures.' To obtain data on villagers' reported perceptions of corruption, in the same set of villages I also conducted a household survey, in which villagers were asked about the likelihood of corruption in the road project.

\footnotetext{
${ }^{1}$ Prominent papers in this literature include Mauro (1995), Knack and Keefer (1995), LaPorta et al. (1999), and Treisman (2000). This literature is surveyed in detail in Rose-Ackerman (2004).
} 
Using these data, I find that villagers' reported perceptions of the likelihood of corruption in the road project do contain information about the level of missing expenditures in the project. Moreover, villagers are sophisticated enough in their reported perceptions to distinguish between general levels of corruption in the village and corruption in the particular road project I examine. However, reported perceptions of corruption contain only a limited amount of information: increasing the missing expenditures measure by $10 \%$ is associated with just a $0.8 \%$ increase in the probability a villager believes that there is any corruption in the project.

One reason villagers' information about corruption may be limited is that officials have multiple methods of hiding corruption, and choose to hide corruption in the places where it is hardest for villagers to detect. In particular, my analysis suggests that villagers are able to detect markedup prices, but appear unable to detect inflated quantities of materials used in the road project. Consistent with this, the vast majority of corruption in the project occurs by inflating quantities, with almost no markup of prices on average. The inability of villagers to detect inflated quantities, combined with the fact that officials can substitute between hiding corruption as inflated prices or inflated quantities, suggests that officials may be strategic in how they hide corruption, and that effective monitoring requires specialist auditors who can detect multiple types of corruption.

The fact that the overall correlation between reported corruption perceptions and missing expenditures is positive, however, is not sufficient to show that the two variables can be used interchangeably as measures of corruption. In particular, reported perceptions may be systematically biased, either because individuals' beliefs are biased, or because conditional on their true beliefs the way individuals report corruption is biased. I first show that, even controlling for village fixed effects (and therefore controlling completely flexibly for the actual level of corruption in the road) and benchmarking for how respondents answer the corruption question in other contexts, individual characteristics such as education and gender systematically predict respondents' reported perceptions of corruption in the road project. 1 show that these biases are not affected by how the respondents are told the information will be used, which suggests they may be biases in the respondents' underlying beliefs rather than simply biases in how respondents choose to report their perceptions in the survey.

Just because individual perceptions are biased does not necessarily mean that, in aggregate, corruption perceptions will give misleading results when investigating the determinants of corruption. To test for aggregate biases that would affect inference about the determinants of corruption, I examine the relationship between the two different measures of corruption and a host of village characteristics. Consistent with other studies, I find, for example, that increased ethnic heterogeneity is associated with higher levels of reported corruption perceptions (e.g., Mauro, 1995; LaPorta et al., 1999), and that increased levels of participation in social activities are associated with lower levels of reported corruption perceptions (e.g., Putnam et al., 1993). But when I examine the relationship between these variables and the missing expenditures variable, I find different results - ethnic heterogeneity is associated with lower levels of missing expenditures, and participation in social activities is not correlated with missing expenditures levels at all.

One hypothesis that could reconcile these differences is that there may be a feedback mechanism, where biased beliefs about corruption lead to more monitoring behavior, which in turn lowers actual corruption. For example, I show that within a given village, respondents who are prone to believe there is more corruption generally (as measured by their corruption perceptions about the President of Indonesia) are more likely to engage in monitoring the village road project. Similarly, villagers in more ethnically heterogeneous villages are less likely to report trusting their fellow villagers, and more likely to attend project monitoring meetings, than those in homogeneous villages, which may explain why there is greater perceived corruption in heterogeneous villages but lower missing expenditures.

More generally, the results suggest that when examining the correlates of corruption, examining perceptions of corruption may lead to misleading conclusions. Instead, more objective methods of measuring corruption, such as the approach used here (or the related approaches used by Di Tella and Schargrodsky, 2003; Reinikka and Svensson, 2004; Fisman and Wei, 2004; Yang, 2004; Hsieh and Moretti, 2006; Olken 2006a), may produce more reliable results.

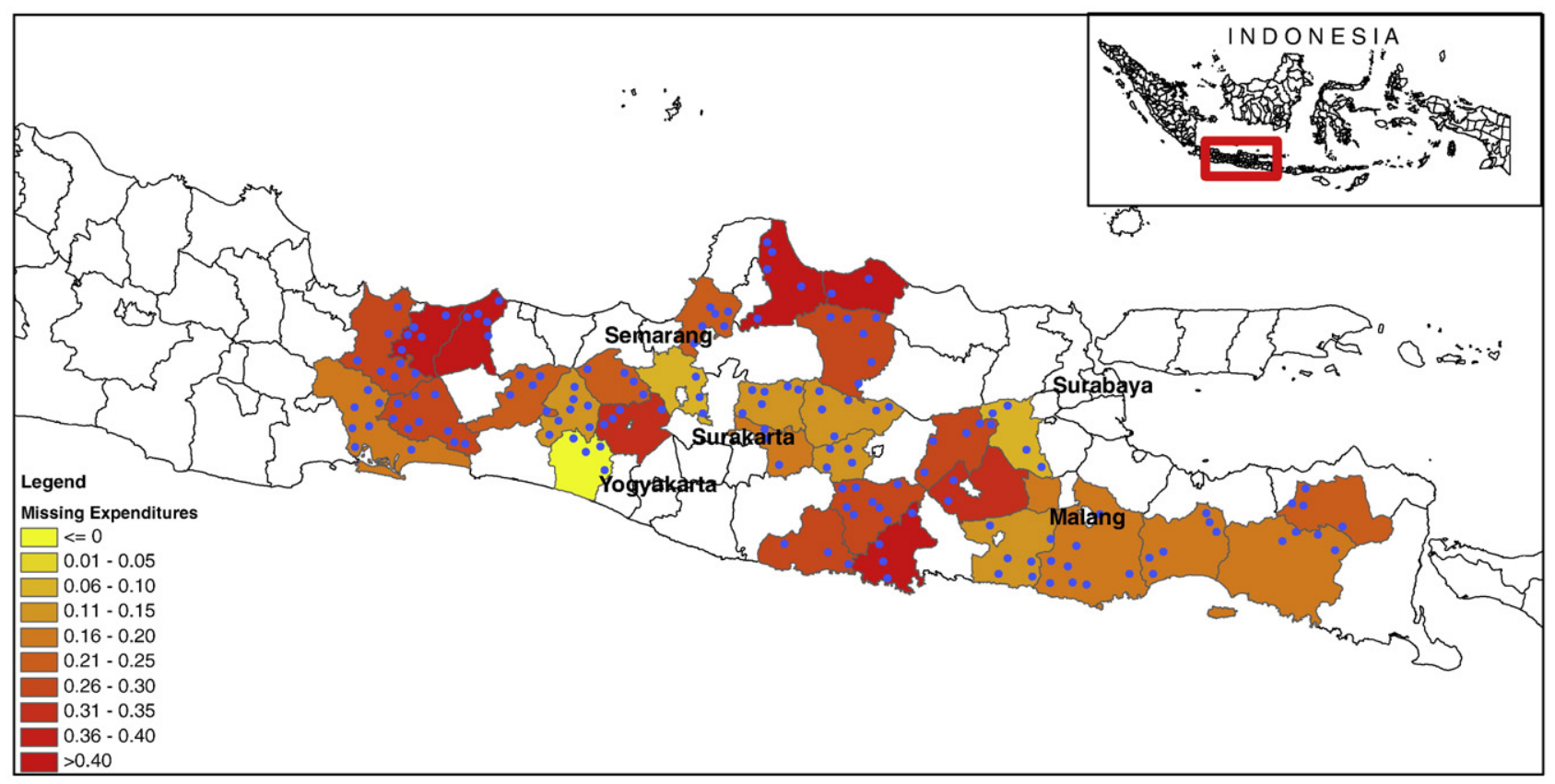

Notes: Each dot shows the location of a study subdistrict. The average level of missing expenditures in the district is indicated by the shading of the district. The major cities of East and Central Java are labeled. 
This paper is related to several literatures in economics that seek to characterize the relationship between reported beliefs and reality more generally. Bertrand and Mullainathan (2001) discuss the psychological underpinnings of biases in answers to subjective survey questions, and there is a large literature examining the accuracy and potential biases in individuals' forecasts of their own future retirement decisions, mortality, and income. ${ }^{2}$ In the public sphere, several authors have also found that reported perceptions are positively correlated with more objective measures of performance, in the very different contexts of international perceptions of bribery (Mocan, 2004), prices paid by Bolivian hospitals for medical supplies (GrayMolina et al., 2001), and principals evaluating teachers (Jacob and Lefgren, 2005). In the setting closest to that examined here, however, Beaman et al. (2008) document that women leaders in Indian villages deliver better public services than male leaders, yet score worse on measures of citizen satisfaction. Their results, consistent with the results presented here, suggest that there may be political market failures caused by inaccuracies in public perceptions about the performance of government officials.

The remainder of this paper is organized as follows. Section 2 discusses the empirical setting and the data used in the paper. Section 3 examines the degree to which individual villagers have information about actual corruption levels. Section 4 examines the degree to which villagers' reported perceptions about corruption are biased. Section 5 concludes.

\section{Setting and data}

\subsection{Empirical setting}

The data in this paper come from 477 villages in two of Indonesia's most populous provinces, East Java and Central Java, as shown in Fig. 1. The villages in this study were selected because they were about to begin building small-scale road projects under the auspices of the Kecamatan (Subdistrict) Development Project, or KDP. KDP is a national government program, funded through a loan from the World Bank, which finances projects in approximately 15,000 villages throughout Indonesia each year. The data in this paper were collected between September 2003 and August 2004.

The roads I examine are built of a mixture of rock, sand, and gravel, range in length from $0.5-3 \mathrm{~km}$, and may either run within the village or run from the village to the fields. A typical road project costs on the order of Rp. 80 million (US\$8,800 at the then-current exchange rate). Under KDP, a village committee receives the funds from the central government, and then procures materials and hires labor directly, rather than using a contractor as an intermediary. The allocation to the village is lump-sum, so that the village is the residual claimant. In particular, surplus funds can be used, with the approval of a village meeting, for additional development projects, rather than having to be returned to the KDP program. These funds are often supplemented by voluntary contributions from village residents, primarily in the form of unpaid labor. A series of three village-level meetings are conducted to monitor the use of funds by the village committee implementing the project.

Corruption in the village projects can occur in several ways. First, village implementation teams, potentially working with the village head, may collude with suppliers to inflate either the prices or the quantities listed on the official receipts. Second, members of the im-

\footnotetext{
${ }^{2}$ For example, Bernheim (1989) discusses systematic variability in individual accuracy in forecasting retirement dates, Hurd and McGarry (1995) document that individuals with certain observable characteristics are systematically more likely to over or under-predict their own mortality, Dominitz and Manski (1997) document that individuals can forecast their expected income, and Bassett and Lumsdaine (1999, 2001 ) discuss how even controlling for observable characteristics, some individuals are likely to be over-optimistic across a wide variety of beliefs whereas others are systematically over-pessimistic.
}

plementation team may manipulate wage payments by inflating the wage rate or the number of workers paid by the project.

The villages in this study were part of a randomized experiment on reducing corruption, described in more detail in Olken (2007). Three experimental treatments were conducted in randomly selected subsets of villages: an increase in the probability of an external government audit of the project, an increase in the number of invitations distributed to the village meetings regularly held to oversee use of project funds, and the distribution of anonymous comment forms. All of the empirical specifications reported below include dummy variables for each of these experimental treatments to ensure that the effects reported here are not being driven by these experiments, though the results below are essentially similar if the experimental dummies are not included. (I discuss the effects of the experiments on reported corruption perceptions in Section 3).

The data used here come from three surveys designed by the author: a household survey, containing data on household beliefs about corruption in the project; a field survey, used to measure missing expenditures in the road project; and a key-informant survey with the village head and the head of each hamlet, used to measure village characteristics. In the subsequent subsections, I describe the two aspects of the data that are the focus of this study - the household survey on corruption perceptions and the field survey to measure missing expenditures in the road project. Additional details about the data collected can be found in Appendix A.

\subsection{Corruption perceptions}

Data on reported corruption perceptions were obtained from a survey of a stratified random sample of adults in the village. The survey was conducted between February 2004 and April 2004, when construction of the road projects was between $80 \%$ and $100 \%$ complete. The sample includes 3691 respondents.

The key corruption question I examine is the following: "Generally speaking, what is your opinion of the likelihood of diversions of money/ KKN (corruption, collusion, and nepotism) involving [...]," where [...] is 1) the President of Indonesia (at the time, Megawati Sukarnoputri), 2) the staff of the subdistrict office (the administrative level above the village), 3) the village head, 4) the village parliament, and 5) the road project. KKN is the Indonesian acronym for corruption, collusion, and nepotism - the catch-all phrase for corruption in Indonesian. Respondents were given 5 possible choices in response - none, low, medium, high, and very high. The first four questions (from the President to the village parliament) were asked, in that order, in the middle of the $1.5 \mathrm{~h}$ survey; the question about the road project was asked towards the end of the survey.

The tabulations of the responses to these corruption questions are given in Table 1. Several things are worth noting about the responses. First, the more 'local' the subject being asked about, the less corruption respondents report - i.e., respondents report the highest corruption levels for the President, followed by the subdistrict staff, followed by the village officials, followed lastly by the road project.

Second, $8.9 \%$ of respondents do not answer the question about corruption in the road project, claiming either they do not know or they do not want to answer. In interviews it appeared that many people who refused to answer did so because they felt uncomfortable saying that there was corruption. Although respondents were assured that responses would remain anonymous, this reluctance to state opinions about corruption is common to many surveys of corruption (Azfar and Murrell, 2005). It is particularly understandable in this context, given that free speech was restricted in Indonesia until the end of the Soeharto government in 1998, and that even now village heads still wield considerable local authority.

I therefore examine two versions of the corruption beliefs variable that deal with these non-responses in different ways. The first version is simply the five ordered categorical responses shown in Table 1, 
Table 1

Summary statistics.

\begin{tabular}{|c|c|c|c|c|c|}
\hline \multicolumn{6}{|l|}{ Panel A: corruption perceptions } \\
\hline Perceived corruption involving & Road project & President & Subdistrict staff & Village head & Village parliament \\
\hline None & $64.1 \%$ & $13.9 \%$ & $22.1 \%$ & $47.1 \%$ & $52.4 \%$ \\
\hline Low & $21.1 \%$ & $12.8 \%$ & $15.6 \%$ & $18.0 \%$ & $14.5 \%$ \\
\hline Medium & $5.3 \%$ & $22.9 \%$ & $14.5 \%$ & $9.5 \%$ & $6.4 \%$ \\
\hline High & $0.4 \%$ & $9.2 \%$ & $1.6 \%$ & $1.8 \%$ & $0.7 \%$ \\
\hline Very high & $0.2 \%$ & $3.4 \%$ & $0.2 \%$ & $0.3 \%$ & $0.1 \%$ \\
\hline Refused to answer & $8.9 \%$ & $37.7 \%$ & $45.9 \%$ & $23.3 \%$ & $25.9 \%$ \\
\hline Num obs. & 3691 & 3691 & 3691 & 3691 & 3691 \\
\hline Panel B: other variables & Mean & Std. Dev. & Min & Max & Num obs. \\
\hline Missing expenditures & 0.237 & 0.343 & -1.103 & 1.674 & 477 \\
\hline Missing expenditures & 0.243 & 0.320 & -1.287 & 1.288 & 477 \\
\hline Missing quantities & -0.014 & 0.210 & -1.031 & 0.783 & 477 \\
\hline Inflated prices & -0.022 & 0.205 & -1.051 & 0.451 & 461 \\
\hline Inflated prices - no project suppliers & 0.046 & 0.258 & -0.941 & 1.076 & 427 \\
\hline Inflated prices - buyers only & 0.237 & 0.343 & -1.103 & 1.674 & 477 \\
\hline \multicolumn{6}{|l|}{ Missing expenditures for materials only } \\
\hline Missing expenditures & 0.203 & 0.395 & -1.255 & 1.878 & 477 \\
\hline Missing quantities & 0.228 & 0.353 & -1.355 & 1.878 & 477 \\
\hline Inflated prices & -0.026 & 0.240 & -1.031 & 0.832 & 476 \\
\hline Inflated prices - no project suppliers & -0.043 & 0.235 & -1.051 & 0.529 & 438 \\
\hline Inflated prices - buyers only & 0.002 & 0.250 & -0.941 & 0.783 & 211 \\
\hline \multicolumn{6}{|l|}{ Household covariates } \\
\hline Education (years) & 7.340 & 3.238 & 0 & 18 & 3686 \\
\hline Age & 41.063 & 11.693 & 18 & 90 & 3691 \\
\hline Female & 0.302 & 0.459 & 0 & 1 & 3691 \\
\hline Predicted log per-capita consumption & 11.473 & 0.284 & 10.620 & 12.898 & 3487 \\
\hline Participation in social activities (number of times in last 3 months) & 22.449 & 20.159 & 0 & 162 & 3691 \\
\hline Participation in social activities in last 3 months where road project likely discussed & 6.801 & 5.907 & 0 & 55.389 & 3472 \\
\hline Lives in project hamlet & 0.553 & 0.497 & 0 & 1 & 3691 \\
\hline Attended development meeting & 0.260 & 0.439 & 0 & 1 & 3662 \\
\hline Family member of village government & 0.301 & 0.459 & 0 & 1 & 3691 \\
\hline Family member of road project leader & 0.058 & 0.234 & 0 & 1 & 3691 \\
\hline Version B of survey form & 0.337 & 0.473 & 0 & 1 & 3667 \\
\hline \multicolumn{6}{|l|}{ Village covariates } \\
\hline Log population & 8.209 & 0.562 & 6.347 & 10.096 & 477 \\
\hline Mean village education level (years) & 4.257 & 1.082 & 1.061 & 7.806 & 472 \\
\hline Share of population poor & 0.407 & 0.212 & 0.019 & 0.945 & 474 \\
\hline Ethnic fragmentation & 0.031 & 0.085 & 0.000 & 0.513 & 472 \\
\hline Religious fragmentation & 0.020 & 0.047 & 0.000 & 0.424 & 472 \\
\hline Intensity of social participation & 11.042 & 11.680 & 0.000 & 87.875 & 459 \\
\hline Meetings with written accountability report & 0.328 & 0.383 & 0.000 & 1.000 & 470 \\
\hline Number of ordinances from village parliament & 3.981 & 3.157 & 0.000 & 22.000 & 471 \\
\hline
\end{tabular}

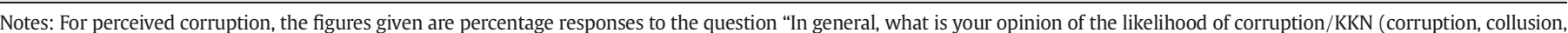

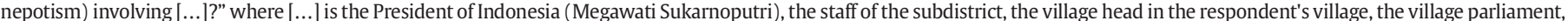
or the road project, as indicated in the columns. Sample is limited to those villages where the missing expenditures variable is not missing.

where "refused to answer" is treated as missing. I use ordered probit models to investigate the determinants of this categorical response variable. The disadvantage of this approach is that it disregards the potentially useful information contained in "refused to answer," namely that those who refuse to answer often believe there is corruption but are unwilling to say so. I therefore create a second version of the beliefs variable called "any likelihood of corruption" that groups all positive likelihood of corruption answers together with non-responses. This variable is equal to 1 if the respondent reports any positive probability of corruption (low, medium, high, or very high) or refused to answer the corruption question, and 0 otherwise. ${ }^{3}$ I use probit models to investigate the determinants of this variable. As will be discussed in more detail below, the two variables produce broadly similar results.

\subsection{Missing expenditures}

The independent measure of corruption I use is "missing expenditures" in the road project. Missing expenditures are the difference in logs

\footnotetext{
${ }^{3}$ Alternatively, if I use a dummy variable for any positive perceptions of corruption, but drop missings rather than count them as a positive perception, the results are slightly weaker than the results presented. This is consistent with the idea that a nonresponse is associated with a positive perceived corruption probability.
}

between what the village claimed it spent on the project and an independent estimate of what it actually spent. This measure is approximately equal to the percent of expenditures on the road project that cannot be accounted for by the independent estimate of expenditures.

Obtaining data on what villages claim they spent is relatively straightforward. At the end of the project, all village implementation teams were required by KDP to file an accountability report with the project subdistrict office, in which they reported the prices, quantities, and total expenditure on each type of material and each type of labor (skilled, unskilled, and foreman) used in the project. The total amount reported must match the total amount allocated to the village. These reports were obtained from the village by the survey team.

Obtaining an independent estimate of what was actually spent was substantially more difficult, and involved three main activities - an engineering survey to determine quantities of materials used, a worker survey to determine wages paid by the project, and a supplier survey to determine prices for materials. In the engineering survey, an engineer and an assistant conducted a detailed physical assessment of all physical infrastructure built by the project in order to obtain an estimate of the quantity of main materials (rocks, sand, and gravel) used. In particular, to estimate the quantity of each of these materials used in the road, the engineers dug ten $40 \mathrm{~cm} \times 40 \mathrm{~cm}$ core samples at randomly selected locations on the road and measured the quantities of each material in 


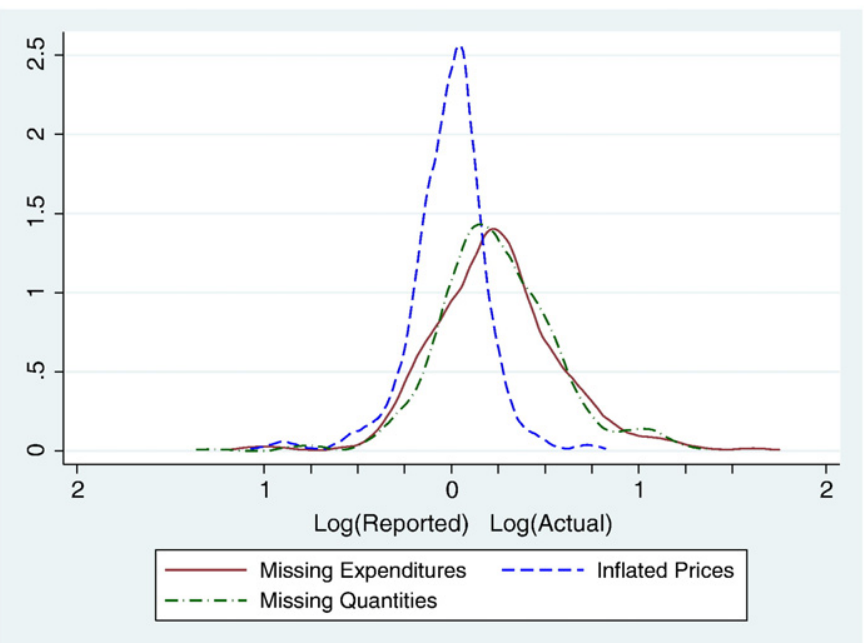

Notes: The graph shows kernel density estimates of the PDFs of the missing expenditures, missing quantities, and inflated prices variables.

Fig. 2. Distributions of missing expenditures.

each core sample. By combining the measurements of the volume of each material per square meter of road with measurements of the total length and average width of the road, I can estimate the total quantity of materials used in the road. I also conducted calibration exercises to estimate a "loss ratio," i.e., the fraction of materials that are typically lost are lost as part of the normal construction process. ${ }^{4}$

To measure the quantity of labor, workers were asked which of the many activities involved in building the road were done with paid labor, voluntary labor, or some combination, what the daily wage and number of hours worked was, and to describe any piece rate arrangements that may have been part of the building of the project. To estimate the quantity of person-days actually paid out by the project, I combine information from the worker survey about the percentage of each task done with paid labor, information from the engineering survey about the quantity of each task, and assumptions of worker capacity derived both from the experience of field engineers and the experience from building the calibration roads.

To measure prices, a price survey was conducted in each subdistrict. Since there can be substantial differences in transportation costs within a subdistrict, surveyors obtained prices for each material that included transportation costs to each survey village. The price survey included several types of suppliers - supply contractors, construction supply stores, truck drivers (who typically transport the materials used in the project), and workers at quarries - as well recent buyers of material (primarily workers at construction sites). For each type of material used by the project, between three and five independent prices were obtained; I use the median price from the survey for the analysis. To minimize the potential for reporting bias, in all cases price surveys were conducted in villages in the subdistrict other than the village for which the data would be used. Respondents were also not informed that the survey was related to an analysis of the road project. ${ }^{5}$

\footnotetext{
${ }^{4}$ For example, some amount of sand may blow away off the top of a truck, or may not be totally scooped out of the hole dug by the engineers conducting the core sample. I estimated the ratio between actual materials used and the amount of materials measured by the engineering survey by constructing four test roads, where the quantities of materials were measured both before and after construction. In calculating missing expenditures, I multiply the estimated actual quantities based on the core samples of the road by this loss ratio to generate the actual estimated level of expenditures on the road project.

5 As with quantities, the "zero corruption" level of the differences in prices might not be 0 ; for example, villages might be able to obtain discounts beyond those our surveyors could obtain. However, it is hard to know what these discounts might be, so I do not have a way of calibrating the analogous "loss ratio" for prices as I did for quantities.
}

From these data - reported and actual quantities and prices for each of the major items used in the project - I construct the missing expenditures variable. Specifically, I define the missing expenditures variable to be the difference between the log of the reported amount and the log of the actual amount. As shown in Table 1, on average, after adjusting for the normal loss ratios derived from the calibration exercise, the mean of the missing expenditures variable is 0.24 . Note, however, that while the levels of the missing expenditures variable depend on the loss ratios, the differences in missing expenditures across different villages do not. ${ }^{6}$ As a result, I focus primarily on the differences in missing expenditures across villages rather than on the absolute level of missing expenditures. I also examine several alternative versions of the missing expenditures measures, which separate out missing price and quantities, focus on missing materials expenditures only (i.e., exclude labor), and use various subsets of respondents from the price survey. The mean levels of missing expenditures for each district in the study are shown in Fig. 1, and the PDFs of the missing expenditures, inflated prices and missing quantities variables are shown in Fig. 2.

\section{Comparing perceptions with missing expenditures}

\subsection{The information content of villagers' reported perceptions}

I begin by estimating whether villagers' reported corruption perceptions contain any information about missing expenditures. I consider both versions of the corruption perceptions variable described above - the categorical response variable and a dummy variable for any positive probability of corruption in the road project (including missings as positive responses). I estimate an ordered probit model of the following form:

$$
\mathrm{P}\left(P_{v h}=j\right)=\Phi\left(\theta_{j}-\beta c_{v}-X_{v h}^{\prime} \gamma\right)-\Phi\left(\theta_{j-1}-\beta c_{v}-X_{v h}^{\prime} \gamma\right)
$$

where $P$ is the respondent's answer to the question about perceptions of corruption in the road project, $c$ is the estimate of missing expenditures in the road project, $v$ represents a village, $h$ represents a household, $j$ is one of the $J$ categorical answers to the corruption perception question, $\theta_{j}$ is a cutoff point estimated by the model (with $\theta_{0}=-\infty$ and $\left.\theta_{J}=\infty\right), X_{v h}$ are dummies for how the household was sampled, which version of the form the respondent received, and the experimental treatments, and $\Phi$ is the Normal CDF. The test of whether individuals' corruption perceptions have information is a test of whether the coefficient $\beta>0$. For the dummy variable version of the perceptions variable, I estimate the equivalent probit equation (i.e., with only one threshold level $\theta_{j}$ ). Standard errors are adjusted for clustering at the subdistrict level, to take into account the fact that there are multiple respondents $h$ in a single village $v$ and that the missing expenditures variable may be correlated across villages in a given subdistrict. ${ }^{7}$

The results are presented in columns (1) and (4) of Table 2 for the categorical and dummy variables, respectively. Note that to facilitate interpretation, for the probit specification in column (4) I present

\footnotetext{
${ }^{6}$ To see this, note that the loss ratio is a multiplicative constant for each component of the road. If there was only one type of material used the project, then since missing expenditures are expressed as the differences in logs, the loss ratio is simply an additive constant. With multiple components (e.g., rocks, sand, gravel, etc), the additive constant varies slightly from village to village, depending on the relative weights of the different components in different villages. These differences are small however, so that changes in the loss ratios do not substantively affect the results.

${ }^{7}$ There are 143 subdistricts in the sample. One subdistrict therefore includes an average of 3.3 villages, so clustering at the subdistrict is more conservative than clustering at the village level. Clustering at the village level reduces the standard errors from those presented in the table.
} 
Table 2

Relationship between perceptions and missing expenditures.

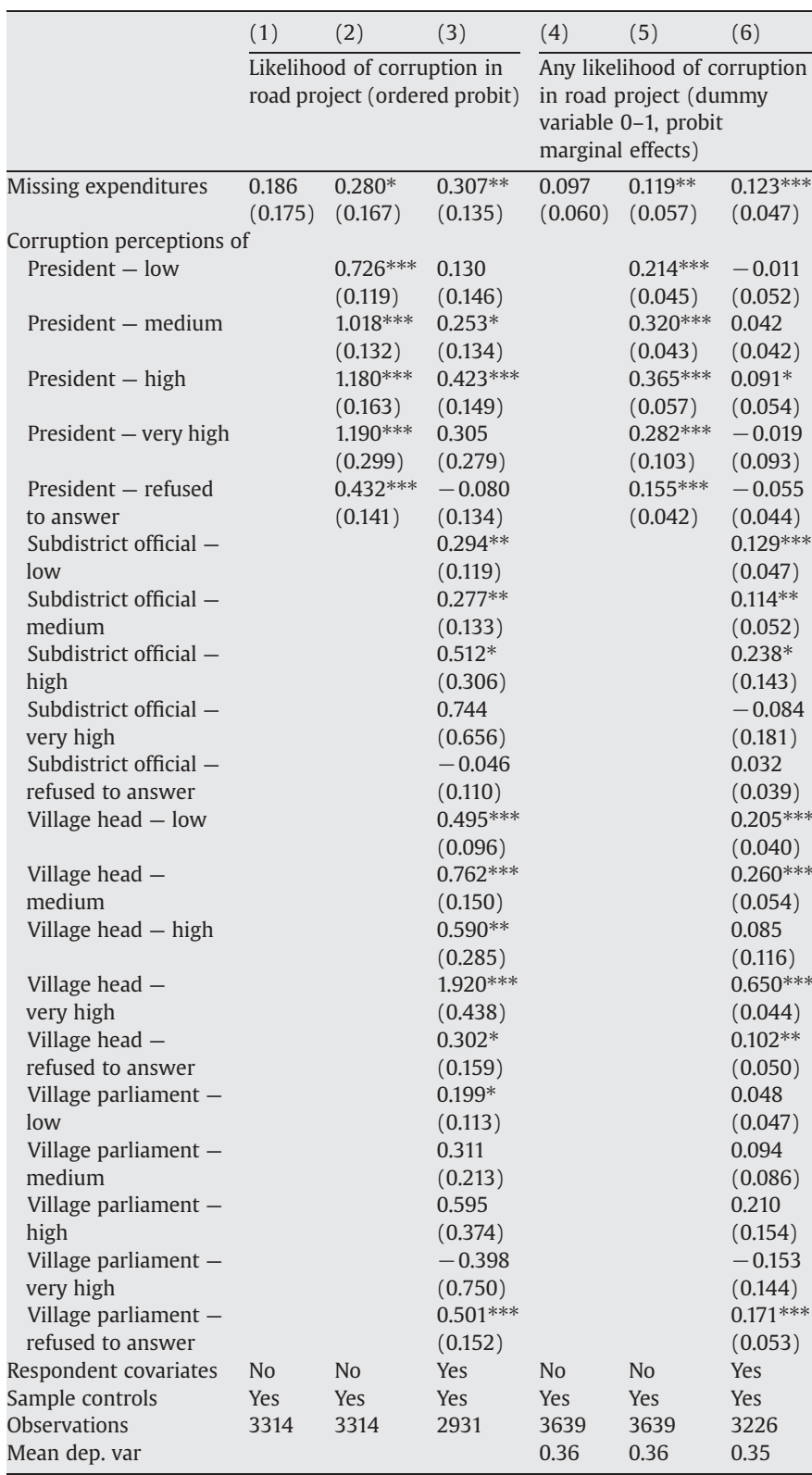

Notes: Robust standard errors in parentheses, clustered at the subdistrict level. In columns (1)-(3), the dependent variable is the categorical responses to the perceptions question, i.e., 'none', 'low', 'medium', 'high' and 'very high' (in that order). In columns (4)-(6), the dependent variable is a dummy that takes value 0 if answer was 'none' and 1 if answer was 'low', 'medium', 'high', 'very high', or if the respondent refused to answer. Corruption perceptions of President, subdistrict official, village head, and village parliament are dummies for respondent's perceived corruption levels of the respective officials. Respondent covariates are age, education, gender, predicted percapita expenditure, participation in social activities, relationship to government and project officials. Sample controls are dummies for the three experimental interventions (audit, invitations, and invitations + comment forms), dummies for the different strata of respondents sampled, and a dummy for which version of the form the respondent received.

*Significant at $10 \%$; **Significant at $5 \%$; ***Significant at $1 \%$.

marginal effects. Both results show a positive coefficient on the missing expenditures variable, though neither coefficient is statistically significant.

A respondent's answers about a particular type of corruption may be colored by the respondent's attitudes about corruption in general. The responses to the corruption question may also differ if individuals perceive the levels of the scale (i.e., 'none,' low,' etc.) differently. To correct for these factors, I benchmark the respondent's attitudes about corruption in general by using the respondent's answer to the question about the likelihood that there is corruption involving the President of Indonesia. As discussed above, the phrasing of the corruption question is the same as the question about the road project, but in this case all respondents are evaluating the same individual - the President of Indonesia. Since the person being evaluated is the same for all respondents, the different answers to this question captures general differences in the way the respondents evaluate corruption and answer the perceptions question. ${ }^{8}$ This is analogous to the approach taken by Bassett and Lumsdaine (1999), who use responses to a question about the probability of the weather being sunny tomorrow to benchmark the overall optimism or pessimism of the respondents when interpreting questions about the respondent's beliefs about future events. ${ }^{9}$

The results controlling for dummies corresponding to the different possible answers to the question about how corrupt the President is are presented in columns (2) and (5). The responses to the corruption question on the road project and the corruption question about the President are positively correlated (the dummy versions of these variables have correlation coefficient $0.16, p<0.001$ ). Controlling for perceptions of how corrupt the President is substantially strengthens the results, increasing both the magnitudes and the statistical significance in both specifications. ${ }^{10}$

However, even controlling for the individual's response about how corrupt the President is, it is possible that the correlation between missing expenditures in the road project and perceptions of corruption in the road project reflects only villagers' perceptions of the average levels of corruption in their village, rather than specific information about the road project per se.

To examine whether villagers have specific information about the road project per se, I estimate an alternative version of Eq. (1) that also controls as flexibly as possible for villagers' reported perceptions about the general level of corruption in the village, denoted by $q$ :

$$
\begin{aligned}
\mathrm{P}\left(P_{v h}=j\right)= & \Phi\left(\theta_{j}-\beta c_{v}-X_{v h}^{\prime} \gamma-q^{\prime} \delta\right) \\
& -\Phi\left(\theta_{j-1}-\beta c_{v}-X_{v h}^{\prime} \gamma-q^{\prime} \delta\right) .
\end{aligned}
$$

To capture as flexibly as possible the respondents' general corruption perceptions $q$, I include in $q$ the respondents' answers to the corruption questions about subdistrict officials, the village head, and

\footnotetext{
${ }^{8}$ One might be concerned that corruption perceptions of the President may also capture heterogeneity in overall attitudes towards the President of Indonesia rather than just benchmarking for how the respondent answers the corruption question. However, controlling for the respondent's overall approval of the President's job performance, rather than how corrupt they think the President is, has no effect on the correlation between perceptions of corruption in the road project and the missing expenditures variable. Conversely, controlling for any of the respondent's other answers to the corruption question - i.e., perceptions of subdistrict officials, village head, or village parliament - has a similar effect to controlling for the corruption of the President, although slightly smaller in magnitude. This suggests that the effect of controlling for perceptions of the President's corruption is due to capturing differential interpretations of the corruption question, rather than individual opinions of the President.

${ }^{9}$ This benchmarking exercise is also related to the anchoring vignettes literature in political science, discussed by King et al. (2004). The advantage of the approach used here relative to benchmarking against a hypothetical vignette is that the approach here captures differences in the respondents' reluctance to report corruption (due, for example, to fear of retaliation), which would not be captured in a hypothetical question.

${ }^{10}$ A natural question is why controlling for beliefs about the President changes the point estimates on the correlation, rather than just reduces the standard errors. However, if all people in a certain area believe there is more corruption, they may monitor more, reducing actual corruption levels. In fact, as discussed in Section 4.2 below, the data is consistent with this mechanism - individuals who report any corruption in involving the President are more likely to attend one of the project accountability meetings. Such a mechanism would attenuate the raw correlation between beliefs and actual corruption unless one also controls for the overall average beliefs about corruption.
} 
the village parliament (none of whom have any official role in the road project), as well as a variety of respondent-level control variables age, gender, per-capita expenditure (predicted from assets), participation in social activities, and family relationships to government and project officials. (The role of these respondent-level variables in predicting perceptions will be discussed in more detail in Section 1 below.) As can be seen in columns (3) and (6) of Table 2, adding these many additional control variables reduces the standard errors but does not change the point estimates. This is despite the fact that, to take just one example, the correlation of respondents' perceptions of corruption involving the village head and corruption involving the road project is 0.4 . Thus, despite the relatively high correlation of these perceptions of different types of corruption, the results suggest that villagers are actually able to distinguish between general levels of corruption in the village and corruption in the road project in particular.

To interpret the magnitudes of the estimated coefficients, consider the probit specification. The point estimate in column (6) suggests that a $10 \%$ increase in missing expenditures above the mean level - i.e. an increase of 0.024 from the mean level of 0.24 - would be associated with an increase in the probability the respondent reports any corruption in the project of 0.0030 , or an increase of about $0.8 \%$ over the mean level of 0.36 . Put another way, the "elasticity" of a respondent reporting any likelihood of corruption with respect to the missing expenditures variable is about 0.08 . Calculating the marginal effects from the ordered probit specifications gives results of similar magnitudes. While there is information about actual corruption levels in perceptions, the magnitude of this information is weak.

An important question is whether this weak correlation is merely the result of measurement error in the missing expenditures measure, or actually reflects the fact that households have little information. Recall that to construct the missing expenditures measure, I used data from 10 core samples of each road, and between 3 and 5 price quotations for each type of material used. To investigate the role of measurement error, for each road I randomly split these 10 core

Table 3

Investigating measurement error.

\begin{tabular}{|c|c|c|c|}
\hline & (1) & $(2)$ & (3) \\
\hline & \multicolumn{3}{|c|}{$\begin{array}{l}\text { Any likelihood of corruption in road project } \\
\text { (dummy variable } 0-1 \text { ) }\end{array}$} \\
\hline \multicolumn{4}{|l|}{ Panel A: OLS linear model } \\
\hline Missing expenditures & $\begin{array}{l}0.096 \\
(0.059)\end{array}$ & $\begin{array}{l}0.117^{* *} \\
(0.055)\end{array}$ & $\begin{array}{l}0.109 * * \\
(0.042)\end{array}$ \\
\hline \multicolumn{4}{|l|}{ Corruption perceptions of } \\
\hline President & No & Yes & Yes \\
\hline Subdistrict official & No & No & Yes \\
\hline Village head & No & No & Yes \\
\hline Village parliament & No & No & Yes \\
\hline Respondent covariates & No & No & Yes \\
\hline Sample controls & Yes & Yes & Yes \\
\hline Observations & 3639 & 3639 & 3226 \\
\hline Mean dep. var & 0.36 & 0.36 & 0.35 \\
\hline \multicolumn{4}{|c|}{ Panel B: IV for measurement error } \\
\hline Missing expenditures & $\begin{array}{l}0.111^{*} \\
(0.061)\end{array}$ & $\begin{array}{l}0.131^{* *} \\
(0.058)\end{array}$ & $\begin{array}{l}0.128 * * \\
(0.044)\end{array}$ \\
\hline \multicolumn{4}{|l|}{ Corruption perceptions of } \\
\hline President & No & Yes & Yes \\
\hline Subdistrict official & No & No & Yes \\
\hline Village head & No & No & Yes \\
\hline Village parliament & No & No & Yes \\
\hline Respondent covariates & No & No & Yes \\
\hline Sample controls & Yes & Yes & Yes \\
\hline Observations & 3639 & 3639 & 3226 \\
\hline Mean dep. var & 0.36 & 0.36 & 0.35 \\
\hline
\end{tabular}

Notes: See notes to Table 2. Panel A replicates columns (4)-(6) of Table 2 using a linear probability model, rather than probit. Panel B replicates the same regressions instrumenting for missing expenditures calculated using half of the core samples with missing expenditures calculated using the other half of the core samples.
Table 4

Accuracy - prices vs. quantities.

\begin{tabular}{|c|c|c|c|c|c|c|}
\hline & (1) & $(2)$ & (3) & $(4)$ & $(5)$ & (6) \\
\hline & \multicolumn{3}{|c|}{$\begin{array}{l}\text { Likelihood of corruption in } \\
\text { road project (ordered } \\
\text { probit) }\end{array}$} & \multicolumn{3}{|c|}{$\begin{array}{l}\text { Any likelihood of } \\
\text { corruption in road project } \\
\text { (dummy variable } 0-1 \text {, } \\
\text { probit marginal effects) }\end{array}$} \\
\hline Inflated prices & $\begin{array}{l}0.433 \\
(0.277)\end{array}$ & $\begin{array}{l}0.627 * * \\
(0.270)\end{array}$ & $\begin{array}{l}0.669 * * * \\
(0.251)\end{array}$ & $\begin{array}{l}0.177^{*} \\
(0.096)\end{array}$ & $\begin{array}{l}0.205^{* *} \\
(0.091)\end{array}$ & $\begin{array}{l}0.204^{* *} \\
(0.081)\end{array}$ \\
\hline Missing quantities & $\begin{array}{l}0.057 \\
(0.183)\end{array}$ & $\begin{array}{l}0.118 \\
(0.177)\end{array}$ & $\begin{array}{l}0.112 \\
(0.155)\end{array}$ & $\begin{array}{l}0.049 \\
(0.062)\end{array}$ & $\begin{array}{l}0.069 \\
(0.060)\end{array}$ & $\begin{array}{l}0.070 \\
(0.053)\end{array}$ \\
\hline \multicolumn{7}{|l|}{ Corruption perceptions of } \\
\hline President & No & Yes & Yes & No & Yes & Yes \\
\hline Subdistrict official & No & No & Yes & No & No & Yes \\
\hline Village head & No & No & Yes & No & No & Yes \\
\hline Village parliament & No & No & Yes & No & No & Yes \\
\hline Respondent covariates & No & No & Yes & No & No & Yes \\
\hline Sample controls & Yes & Yes & Yes & Yes & Yes & Yes \\
\hline Observations & 3314 & 3314 & 2931 & 3639 & 3639 & 3226 \\
\hline Mean dep. var & & & & 0.36 & 0.36 & 0.35 \\
\hline
\end{tabular}

Notes: See notes to Table 2.

*Significant at $10 \%$; $* *$ Significant at $5 \%$; ***Significant at $1 \%$.

samples and 3-5 price quotations into two groups of 5 core samples and 1-3 price quotations each, and use these subsamples of measurements to construct two different estimates of missing expenditures for each village. I then repeat the regressions in columns (4)-(6) of Table 2 instrumenting for the measure of missing expenditure constructed using the first set of measurements with the measure of missing expenditure constructed using the second set of measurements. For comparison, OLS results (analogous to columns 4-6 of Table 2) are shown in Panel A of Table 3; the results using instrumental variables to correct for measurement error are shown in Panel B of Table 3. The estimates in Panel B are only slightly larger than in Panel A (e.g., the coefficient in column (3) increases from 0.109 in the OLS to 0.128 in the IV correcting for measurement error). Thus, at least to the extent I can detect it here, measurement error alone does not seem to explain the low correlation between perceptions and missing expenditures.

\subsection{Differential accuracy: prices vs. quantities}

There are multiple methods village officials can use to hide corruption, and some of these methods may be easier for villagers to detect than others. In particular, village officials who steal a given amount have two options for how to account for this missing money in the accounts - they can either inflate the price paid for the materials procured, or they can inflate the quantities of the materials procured (or both). To examine how perceptions of corruption are formed, I re-estimate Eq. (1) with the missing expenditures variable separated into variables representing its constituent parts - "inflated prices" and "missing quantities." Specifically, I define "inflated prices" as the difference in logs between the prices reported by the village and the prices measured by the independent survey team, weighted by the quantities reported by the village; similarly, I define "missing quantities" as the difference in logs between the quantities reported by the village and the quantities measured by the independent survey team, weighted by the prices reported. "Inflated prices" therefore captures markups in prices, while "missing quantities" captures markups in quantities.

The results are presented in Table 4 . All specifications confirm that villagers' perceptions of corruption in the project are strongly positively correlated with price markups, and only very weakly (and statistically insignificantly) correlated with markups in quantities. The estimated magnitudes for inflated prices are approximately double the magnitudes for missing expenditures overall. Market prices for commodities are commonly known to villagers, but quantities of commodities delivered are very difficult to estimate without careful 
Table 5

Robustness to alternative missing expenditures measures.

\begin{tabular}{|c|c|c|c|c|c|c|}
\hline & $(1)$ & $(2)$ & $(3)$ & \multirow{2}{*}{$\begin{array}{l}\text { (4) } \\
\text { Any like } \\
\text { (dummy }\end{array}$} & $(5)$ & $(6)$ \\
\hline & \multicolumn{3}{|c|}{ Likelihood of corruption in road project (ordered probit) } & & \multicolumn{2}{|c|}{$\begin{array}{l}\text { Any likelihood of corruption in road project } \\
\text { (dummy variable } 0-1 \text {, probit marginal effects) }\end{array}$} \\
\hline \multicolumn{7}{|l|}{ Panel A: materials only } \\
\hline Missing materials expenditures & $\begin{array}{l}0.160 \\
(0.148)\end{array}$ & $\begin{array}{l}0.281^{* *} \\
(0.142)\end{array}$ & $\begin{array}{l}0.313^{* * *} \\
(0.116)\end{array}$ & $\begin{array}{l}0.078 \\
(0.052)\end{array}$ & $\begin{array}{l}0.105^{* *} \\
(0.049)\end{array}$ & $\begin{array}{l}0.108 * * * \\
(0.041)\end{array}$ \\
\hline Observations & 3314 & 3314 & 2931 & 3639 & 3639 & 3226 \\
\hline \multicolumn{7}{|l|}{ Panel B: materials only } \\
\hline Missing materials expenditures - prices & $\begin{array}{l}0.418^{*} \\
(0.230)\end{array}$ & $\begin{array}{l}0.611 * * * \\
(0.231)\end{array}$ & $\begin{array}{l}0.659 * * * \\
(0.220)\end{array}$ & $\begin{array}{l}0.171^{* *} \\
(0.081)\end{array}$ & $\begin{array}{l}0.201 * * * \\
(0.078)\end{array}$ & $\begin{array}{l}0.199 * * * \\
(0.070)\end{array}$ \\
\hline Missing materials expenditures - quantities & $\begin{array}{l}0.008 \\
(0.163)\end{array}$ & $\begin{array}{l}0.101 \\
(0.153)\end{array}$ & $\begin{array}{l}0.115 \\
(0.133)\end{array}$ & $\begin{array}{l}0.023 \\
(0.055)\end{array}$ & $\begin{array}{l}0.051 \\
(0.052)\end{array}$ & $\begin{array}{l}0.056 \\
(0.046)\end{array}$ \\
\hline Observations & 3308 & 3308 & 2925 & 3633 & 3633 & 3220 \\
\hline \multicolumn{7}{|c|}{ Panel C: materials only, exclude price quotes from KDP project suppliers } \\
\hline Missing materials expenditures - prices & $\begin{array}{l}0.402 \\
(0.255)\end{array}$ & $\begin{array}{l}0.606 * * \\
(0.255)\end{array}$ & $\begin{array}{l}0.671^{* * *} \\
(0.233)\end{array}$ & $\begin{array}{l}0.170^{*} \\
(0.088)\end{array}$ & $\begin{array}{l}0.200 * * \\
(0.085)\end{array}$ & $\begin{array}{l}0.206 * * * \\
(0.075)\end{array}$ \\
\hline Missing materials expenditures - quantities & $\begin{array}{l}-0.009 \\
(0.202)\end{array}$ & $\begin{array}{l}0.082 \\
(0.189)\end{array}$ & $\begin{array}{l}0.101 \\
(0.156)\end{array}$ & $\begin{array}{l}0.027 \\
(0.065)\end{array}$ & $\begin{array}{l}0.054 \\
(0.062)\end{array}$ & $\begin{array}{l}0.065 \\
(0.052)\end{array}$ \\
\hline Observations & 3046 & 3046 & 2683 & 3358 & 3358 & 2970 \\
\hline \multicolumn{7}{|c|}{ Panel D: materials only, use price quotes from buyers only } \\
\hline Missing materials expenditures - prices & $\begin{array}{l}0.212 \\
(0.307)\end{array}$ & $\begin{array}{l}0.391 \\
(0.303)\end{array}$ & $\begin{array}{l}0.359 \\
(0.263)\end{array}$ & $\begin{array}{l}0.124 \\
(0.098)\end{array}$ & $\begin{array}{l}0.158^{*} \\
(0.096)\end{array}$ & $\begin{array}{l}0.120 \\
(0.089)\end{array}$ \\
\hline Missing materials expenditures - quantities & $\begin{array}{l}0.051 \\
(0.238)\end{array}$ & $\begin{array}{l}0.044 \\
(0.211)\end{array}$ & $\begin{array}{l}-0.002 \\
(0.185)\end{array}$ & $\begin{array}{l}0.029 \\
(0.074)\end{array}$ & $\begin{array}{l}0.031 \\
(0.070)\end{array}$ & $\begin{array}{l}0.027 \\
(0.074)\end{array}$ \\
\hline Observations & 1484 & 1484 & 1353 & 1650 & 1650 & 1499 \\
\hline \multicolumn{7}{|l|}{ Notes for all panels } \\
\hline \multicolumn{7}{|l|}{ Corruption perceptions of } \\
\hline President & No & Yes & Yes & No & Yes & Yes \\
\hline Subdistrict official & No & No & Yes & No & No & Yes \\
\hline Village head & No & No & Yes & No & No & Yes \\
\hline Village parliament & No & No & Yes & No & No & Yes \\
\hline Respondent covariates & No & No & Yes & No & No & Yes \\
\hline Sample controls & Yes & Yes & Yes & Yes & Yes & Yes \\
\hline
\end{tabular}

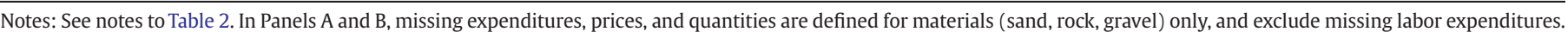

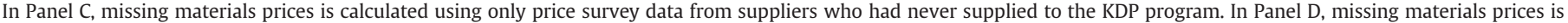
calculated using only price survey data from buyers of materials, not sellers.

*Significant at $10 \%$; **Significant at $5 \%$; ***Significant at $1 \%$.

measurement, even for trained engineers; therefore, it is not surprising that villagers are better at detecting marked-up prices than inflated quantities.

Given this result, it is interesting to compare the overall average levels of the inflated prices and missing quantities variables. After all, if villagers can detect marked-up prices but cannot detect markedup quantities, village officials would in general choose to hide their corruption by inflating quantities rather than marking up prices. As discussed above, one needs to interpret the levels of the missing expenditures variables with caution, because the levels of these variables depend on assumptions about the loss ratios and on the ability of surveyors to obtain exactly the same prices as the villages procuring the material for the project. Nevertheless, the levels of the inflated prices and quantities variables are precisely what one would expect given the perceptions' results: all of the missing expenditures are hidden by inflating quantities, not by inflating prices. Specifically, as shown in Table 1, the mean level of the missing quantities variable is 0.24 , while the mean level of the inflated prices variable is -0.014 , very close to zero. ${ }^{11}$ Thus, on average the vast majority of the missing expenditures appears to be occurring exactly where villagers cannot detect it. This raises the possibility that the relatively low correlation between reported perceptions and missing expenditures may in part reflect the strategic behavior of savvy corrupt officials who deliber-

\footnotetext{
${ }^{11}$ Inflated prices could be less than 0 if, for example, villages purchasing materials received bulk discounts on purchase prices that were not offered to the independent survey team.
}

ately choose the types of corruption that are hardest to detect. ${ }^{12}$ It also suggests that there may be limits in the degree to which villagers can effectively monitor corruption, at least in the absence of external help detecting it.

\subsection{Robustness to alternative missing expenditures measures}

The missing expenditures measure variable contains four types of data: data from the accounting book for the roads project, data from the engineer's assessment of the road project, a price survey, and a labor survey. Although the accounting data and the engineering data are objective measures, and not subject to reporting biases, it is possible that respondents might systematically misreport their answers to the price or the labor survey. If the same omitted variable - say, ethnic heterogeneity - led to misreporting of corruption perceptions and misreporting on the price and labor components, it is possible that the omitted variable could be generating the correlations uncovered in the previous sections.

To examine this possibility, in Table 5 , I therefore repeat the analysis above using different missing expenditures measures that progressively seek to eliminate as much potential for reporting bias from

\footnotetext{
${ }^{12}$ A natural question is how to reconcile the facts that 1 ) there appears to be no price-markups on average and 2) villagers are able to detect price-markups. The answer is that the fact that the average price-markup being 0 masks the fact that some villages had higher-than-market prices, and others had lower-than-market prices. Villagers appear to detect these differences, and they are correlated with corruption perceptions. Perhaps the village officials in those villages where prices were markedup did not realize that prices would be easier to detect than quantities.
} 
the missing expenditures variable as possible. ${ }^{13}$ First, to exclude potential biases from the labor survey, I examine missing materials expenditures - i.e. missing expenditures on the three main materials (rock, sand, and gravel) that go into the road project. This variable uses no data from the labor survey. Panel A of Table 5 replicates the regressions in Table 2 examining missing materials expenditures, and Panel B replicates the regressions in Table 4 using missing materials prices and missing materials quantities. As is evident from Table 5, these results, which exclude all information from the labor survey entirely, are very similar to the main regression results, suggesting that reporting biases in the labor survey are not driving the results.

To examine potential biases in the price survey, I exploit the fact that the price survey interviewed three different types of respondents - sellers of materials who had supplied materials to any KDP program (KDP is the village infrastructure scheme studied in this paper), sellers of materials who did not supply materials to any KDP program, and a small numbers of independent buyers of materials (i.e., private individuals engaged in construction projects in the area). If there were systematic reporting biases, one would expect them to be most severe for those respondents who actually supplied to the KDP program. Moreover, one would expect very different types of misreporting for sellers and buyers. ${ }^{14}$

Panel C of Table 5 presents results using price data only from nonKDP sellers of materials, and Panel D of Table 5 presents results using price data only from independent buyers of materials. The results in Panel C are virtually identical to the results in Panel B, showing that there is no difference from excluding prices from those who sell to the project. The results in Panel D, where I use information from buyers only, are somewhat smaller and weaker statistically than the main results, but remain positive in all cases and cannot be statistically distinguished from the main results. The slightly smaller point estimates are likely explained by the fact that I have very few buyer observations per village (there are an average of only 0.87 buyers surveyed in the price survey per village (i.e., not all villages had a buyer surveyed), as compared to 6.24 price surveys for all types of observations), increasing measurement error in prices and creating attenuation bias. All told, the results suggest that systematic misreporting on the labor and price components of the missing expenditures survey is not substantially driving the correlations between corruption perceptions and missing expenditures established in the previous section.

\section{Biases and feedback}

\subsection{Are corruption perceptions systematically biased?}

This section examines whether certain types of individuals are systematically biased in their reported perceptions about corruption. To do so, I re-estimate a version of Eq. (2) that includes village fixed effects in addition to respondent-level variables. Since the actual level of corruption in the road project does not vary within the village after all, there is only one road project in each village - if there are no individual biases, then once village fixed effects are included and once I benchmark for how respondents perceive the different possible answers to the corruption question, none of the individual characteristics in the regression should systematically predict corruption perceptions. If they do, then we know that those types of individuals

\footnotetext{
${ }^{13}$ Section 2 below discusses other tests for reporting biases in the corruption perceptions surveys.

${ }^{14}$ It is also important to recall that, as discussed above, all data on the price surveys came from interviews in surrounding villages, not from the village in question. Those being surveyed were also not informed that the survey had anything to do with the road-building project. These two sample design considerations were to minimize the possibility of reporting biases in the price survey.
}

Table 6

Are beliefs systematically biased?

\begin{tabular}{|c|c|c|c|c|}
\hline & $(1)$ & $(2)$ & $(3)$ & (4) \\
\hline & \multicolumn{2}{|c|}{$\begin{array}{l}\text { Likelihood of corruption } \\
\text { in road project } \\
\text { (continuous variable } \\
\text { scaled to 0-1, OLS with } \\
\text { fixed effects) }\end{array}$} & \multicolumn{2}{|c|}{$\begin{array}{l}\text { Any likelihood of } \\
\text { corruption in road project } \\
\text { (dummy variable } 0-1 \text {, } \\
\text { conditional logit model) }\end{array}$} \\
\hline Education (years) & $\begin{array}{l}0.004^{* * *} \\
(0.001)\end{array}$ & $\begin{array}{l}0.002^{* *} \\
(0.001)\end{array}$ & $\begin{array}{l}0.065^{* * *} \\
(0.018)\end{array}$ & $\begin{array}{l}0.051^{* * * *} \\
(0.019)\end{array}$ \\
\hline Age & $\begin{array}{l}-0.001^{* * * *} \\
(0.000)\end{array}$ & $\begin{array}{l}-0.001^{* *} \\
(0.000)\end{array}$ & $\begin{array}{l}-0.003 \\
(0.005)\end{array}$ & $\begin{array}{l}-0.001 \\
(0.005)\end{array}$ \\
\hline Female & $\begin{array}{l}-0.017 * * * \\
(0.005)\end{array}$ & $\begin{array}{l}-0.012^{* *} \\
(0.005)\end{array}$ & $\begin{array}{l}-0.183^{*} \\
(0.105)\end{array}$ & $\begin{array}{l}-0.160 \\
(0.108)\end{array}$ \\
\hline $\begin{array}{l}\text { Predicted per-capita } \\
\text { consumption }\end{array}$ & $\begin{array}{l}0.024 * * * \\
(0.009)\end{array}$ & $\begin{array}{l}0.021 * * \\
(0.009)\end{array}$ & $\begin{array}{l}0.217 \\
(0.193)\end{array}$ & $\begin{array}{l}0.148 \\
(0.199)\end{array}$ \\
\hline Participation in social activities & $\begin{array}{l}0.001 \\
(0.000)\end{array}$ & $\begin{array}{l}0.000 \\
(0.000)\end{array}$ & $\begin{array}{l}0.013 * * \\
(0.006)\end{array}$ & $\begin{array}{l}0.011 * \\
(0.006)\end{array}$ \\
\hline $\begin{array}{l}\text { Participation in social activities } \\
\text { where road project likely } \\
\text { discussed }\end{array}$ & $\begin{array}{l}-0.003^{* * *} \\
(0.001)\end{array}$ & $\begin{array}{l}-0.003^{* *} \\
(0.001)\end{array}$ & $\begin{array}{l}-0.075^{* * *} \\
(0.021)\end{array}$ & $\begin{array}{l}-0.069^{* * *} \\
(0.021)\end{array}$ \\
\hline Lives in project hamlet & $\begin{array}{l}-0.027^{* * * *} \\
(0.005)\end{array}$ & $\begin{array}{l}-0.026^{* * *} \\
(0.005)\end{array}$ & $\begin{array}{l}-0.781^{* * * *} \\
(0.108)\end{array}$ & $\begin{array}{l}-0.764^{* * *} \\
(0.110)\end{array}$ \\
\hline Attended development meeting & $\begin{array}{l}-0.006 \\
(0.005)\end{array}$ & $\begin{array}{l}-0.005 \\
(0.005)\end{array}$ & $\begin{array}{l}-0.312^{* * *} \\
(0.110)\end{array}$ & $\begin{array}{l}-0.320^{* * *} \\
(0.112)\end{array}$ \\
\hline $\begin{array}{l}\text { Family member of village } \\
\text { government }\end{array}$ & $\begin{array}{l}0.008 \\
(0.005)\end{array}$ & $\begin{array}{l}0.006 \\
(0.005)\end{array}$ & $\begin{array}{l}0.043 \\
(0.112)\end{array}$ & $\begin{array}{l}0.021 \\
(0.116)\end{array}$ \\
\hline Family member of project leader & $\begin{array}{l}-0.011 \\
(0.008)\end{array}$ & $\begin{array}{c}-0.009 \\
(0.008)\end{array}$ & $\begin{array}{l}-0.399^{* *} \\
(0.203)\end{array}$ & $\begin{array}{l}-0.402^{* *} \\
(0.205)\end{array}$ \\
\hline Version B of survey form & $\begin{array}{l}0.011 \\
(0.009)\end{array}$ & $\begin{array}{l}0.011 \\
(0.009)\end{array}$ & $\begin{array}{l}0.135 \\
(0.169)\end{array}$ & $\begin{array}{l}0.124 \\
(0.170)\end{array}$ \\
\hline Sample controls & Yes & Yes & Yes & Yes \\
\hline President corruption perception & No & Yes & No & Yes \\
\hline Observations & 3727 & 3727 & 2675 & 2675 \\
\hline$R$-squared & 0.49 & 0.51 & & \\
\hline Mean dep. var & 0.40 & 0.40 & 0.40 & 0.40 \\
\hline Fixed effects & Village & Village & Village & Village \\
\hline$p$-value of joint $F$-test & $<0.01$ & $<0.01$ & $<0.01$ & $<0.01$ \\
\hline
\end{tabular}

See notes to Table 2. President corruption perceptions refers to a dummy for the respondent's response to the corruption question the President of Indonesia, as in Table 2. Robust standard errors in parentheses. All specifications include village fixed effects. Note that the sample size is lower in the conditional logit specification since all villages where there is no variation in the dependent variable are automatically dropped from the conditional logit model.

*Significant at $10 \%$; **Significant at $5 \%$; ***Significant at $1 \%$.

described by the variable in question are systematically biased either towards reporting or not reporting corruption in the project. ${ }^{15}$

Given the incidental parameters problem, rather than estimate an ordered probit or probit model with a large number of dummy variables for each village, I instead estimate an OLS models with village fixed effects using the linearized version of the corruption perception variable (where the categorical responses are put on a scale from 0 to 1 ), and a conditional logit model with the dummy version of the corruption perceptions variable. ${ }^{16}$ The coefficients in the conditional logit models can be interpreted as log odds-ratios.

The results are presented in Table 6. For each dependent variable, I present two sets of results - one with no additional controls, and one controlling for perceptions about the President, to control for the fact

\footnotetext{
${ }^{15}$ In interpreting these results, it is important to note that while I can estimate whether bias exists, I do not know which individuals are 'biased' and which are 'unbiased'. The reason is that the dependent variable, perceptions of corruption, does not have a numeric scale that we know should be comparable to the missing expenditures variable. Thus, unlike the literature evaluating subjective probabilities (e.g., Dominitz and Manski, 1997; Hurd and McGarry, 2002), I cannot say which individuals are right and which are wrong or whether the perceived level of corruption is "right on average"; rather, I can only say that conditional on the actual level of corruption, those with high education are more likely to report higher levels of corruption than those with low levels of education.

${ }^{16}$ Specifically, for the linearized version, I assign a value of 0 to a response of 'none', 1 to a response of 'low', 2 to a response of 'medium', etc. Note that for the dummy version of the variable, I find that linear probability models with fixed effects, rather than conditional logit models, produce qualitatively similar results.
} 
that some respondents may have interpreted the multiple response categories differently from others.

Individual-level biases in reported perceptions appear quite significant. Conditional on village fixed effects, better educated respondents and male respondents tend to report more corruption; those who participate in the types of social activity where the project was likely to be discussed, those who live near the project, and (naturally) those who are related to the head of the project all tend to report less corruption. ${ }^{17}$ Taken together, these individual-level biases are highly significant - the $p$-value from a joint test of these characteristics is less than 0.01 in all specifications.

Not only are these biases statistically significant, they are large in magnitude as well. For example, the results show that each year of education makes an individual between 5 and 7 percentage points more likely to report corruption in the project. This implies that, holding actual corruption levels constant, the "elasticity" of the probability of reporting any likelihood of corruption with respect to the respondent's education is between 0.17 and 0.22 - considerably larger than the impact of the actual missing expenditures variable discussed above.

The main conclusion from these results is that these individual biases are very substantial, especially when compared to the magnitude of the correlation between missing expenditures and reported corruption perceptions found above. This suggests that the signalto-noise ratio in reported perceptions is quite low, which may also help explain the low overall correlation between perceptions and missing expenditures.

\subsection{Biased beliefs vs. biased reporting}

An important question is whether the biases in corruption perceptions documented above represent systematic differences in individuals' true beliefs about the level of corruption, or are instead biases in how individuals report their true beliefs. If there are biases in true beliefs, those biases might affect the degree to which individuals monitor corruption and punish corrupt officials, whereas if they are biases in reporting, they might not. ${ }^{18}$

Since true beliefs cannot be observed directly, it is impossible to conclusively disentangle biased beliefs from biased reporting. However, there are several ways we can begin to make progress on this issue. First, 630 respondents in villages receiving the 'comment form' experimental treatment (Olken, 2007) were randomly allocated to receive one of two versions of the survey form: Form $A$, in which respondents were reminded that their responses to the corruption questions would be confidential, and Form B, in which respondents were told that while their responses to the corruption questions would be confidential, they would be summarized and a summary would be read at a village 'accountability meeting. ${ }^{19}$ The purpose of this randomization was to investigate whether respondents would change the reported amounts of corruption if they knew it the results would feed back into the village monitoring process. ${ }^{20}$

The effects of the Form B treatment are investigated in Table 7. First, Columns (1) and (3) of Table 7 repeat the same regressions in Table 6 on the subsample of individuals where the Form B randomization was conducted, using both the linearized and dummy

\footnotetext{
${ }^{17}$ An interesting question is whether these individual characteristics lead to respondents being more or less accurate at detecting corruption, not just biased. To examine this, I also interacted each of these individual characteristics with the missing expenditures variable. Across a wide range of specifications, I found no evidence of such interactions (results not reported).

${ }^{18}$ A model developing this point explicitly can be found in the working paper version of this paper (Olken, 2006b).

${ }^{19}$ These accountability meetings occur in all villages as part of the normal KDP process; the only difference due to the randomization is whether survey respondents were told that their responses to the corruption question would be included in the aggregated, anonymous comments discussed at the accountability meeting.

${ }^{20}$ Note that all regressions in the paper include a Form B dummy variable, to ensure that this randomization is not affecting the main results.
}

Table 7

Biased beliefs vs. biased reporting?

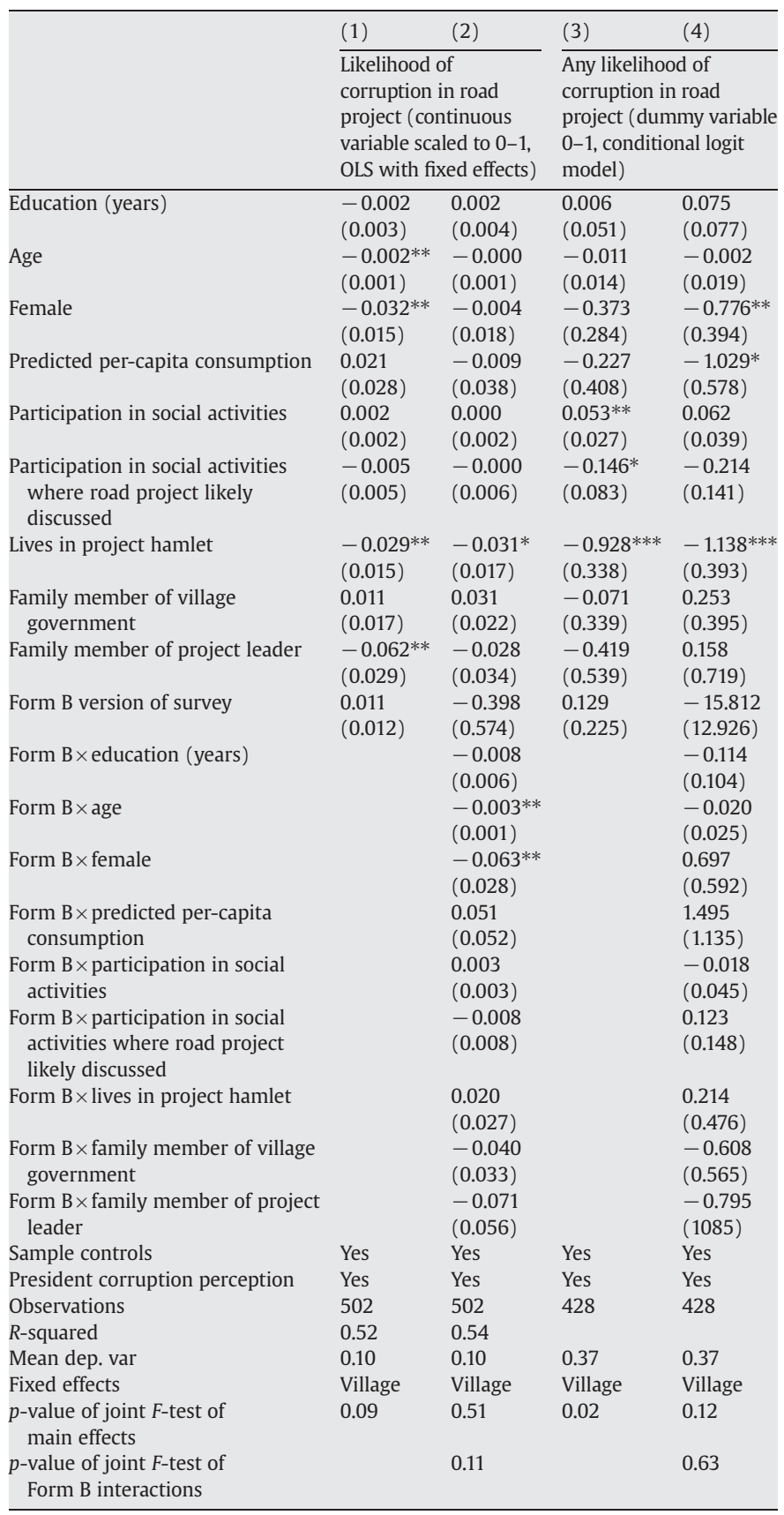

See notes to Table 2. Village head corruption perception and President corruption refer to dummies for the respondent's response to the corruption question about village head and President of Indonesia, respectively, as in Table 2. Robust standard errors in parentheses. All specifications include village fixed effects.

*Significant at $10 \%$; **Significant at $5 \%$; ***Significant at $1 \%$.

versions of the reported corruption perception variable, respectively. ${ }^{21}$ As in Table 6, the linearized versions are analyzed using OLS fixed effects models, and the dummy versions are analyzed using conditional logit models. The coefficient on receiving the Form B treatment shows no significant differences in the average level of reported corruption between the two versions of the form.

\footnotetext{
21 The one variable from Table 6 that is not included is the "attend development meeting" variable, because those households who were sampled because they attended the development meetings were not included in the Form A/Form B experiment. The number of observations in these regressions is less than 630 due to the missing values of several covariates.
} 
Next, columns (2) and (4) of Table 7 report results where I interact all of the respondent characteristics in Table 6 with the Form B dummy. To the extent that the individual-level biases documented in Table 6 are reporting biases, rather than belief biases, we expect them to be more pronounced with the Form B version of the form - i.e., reporting biases should be more pronounced for those people who are told that their responses will actually be used to inform the political decisions surrounding monitoring the project. The $p$-value from a joint test of all interactions is included at the bottom of the table.

The results from this test provide little evidence for systematic reporting biases. Only two interactions with the Form B variable (with respondent age and a female dummy) are statistically significant, and even these variables are only significant on the linearized variable, not the categorical variable. In fact, the point estimate on the Form $\mathrm{B} \times$ female variable is actually of the opposite sign in column (4) when the dummy corruption variable is used. The $p$-value from the joint test of all Form $B$ interactions is 0.11 in column (2) (linearized corruption variable) and 0.63 in column (4) (dummy corruption variable). Though this test is by no means definitive, it suggests that many of the biases found here may represent biases in beliefs rather than biases in reporting.

A second way of examining whether the biases in corruption perceptions shown in Table 6 are actually biases in beliefs is to examine whether they translate into different levels of monitoring activity, i.e., are those individuals who report that there is more corruption more likely to participate in monitoring local officials? To separate out biases in beliefs from actual information about corruption, I consider the following question: conditional on village fixed effects (so holding actual levels of corruption constant), are those individuals who report that the President of Indonesia is more likely to be corrupt more likely to attend monitoring meetings for the road project? By looking at corruption perceptions about the President of Indonesia, rather than the road project, I isolate the relationship between monitoring and general attitudes about corruption, and exclude idiosyncratic information the respondent might have had about the road project per se that might cause him or her to attend a monitoring meeting.

To investigate this, Table 8 presents the results from a conditional logit regression, where the dependent variable is a dummy for attending either any village meeting about the road project (columns 1 and 2) or attending an 'accountability meeting' for the road project (columns 3 and 4), where village officials are required to account for how they spent the project funds. The key independent variable is corruption perceptions of the President, either the linear measure (columns 1 and 3 ) or the dummy variable version (columns 2 and 4 ). All household controls from Table 6 are included in the regression, and the village is the conditioning variable. The coefficients can be interpreted as log odds-ratios.

The results show that those individuals who report that the President of Indonesia is likely to be corrupt are substantially more likely to attend monitoring meetings about the road project. Taking the point estimates in column (4), for example, individuals who report any corruption involving the President of Indonesia are 58\% (0.458 log points) more likely to attend project monitoring meetings than individuals who do not report any corruption involving the President. These results provide suggestive evidence not only that some of the biases in reported corruption may represent real beliefs, not just reporting biases, but also that these biases in beliefs may translate into real monitoring behavior.

\subsection{Are aggregate biases substantial?}

The previous section showed that certain types of individuals are systematically biased in their perceptions of corruption, and presented some suggestive evidence that these biases are correlated with actual decisions about how much to monitor potentially corrupt officials. For these biases to feed back to affect monitoring and, ultimately, corruption levels, these individual biases would have to be both large and correlated with village characteristics.

\section{Table 8}

Corruption perception and attendance at monitoring meetings.

\begin{tabular}{|c|c|c|c|c|}
\hline & $(1)$ & (2) & $(3)$ & (4) \\
\hline & \multicolumn{2}{|c|}{$\begin{array}{l}\text { Attend any village } \\
\text { meeting about the } \\
\text { road project } \\
\text { (dummy variable } \\
0-1 \text {, conditional } \\
\text { logit model) }\end{array}$} & \multicolumn{2}{|c|}{$\begin{array}{l}\text { Attend village } \\
\text { accountability meeting } \\
\text { for road project } \\
\text { (dummy variable } 0-1 \text {, } \\
\text { conditional logit model) }\end{array}$} \\
\hline $\begin{array}{l}\text { Corruption perceptions of President } \\
\text { (linearized from } 0-1 \text { ) }\end{array}$ & $\begin{array}{l}0.160 * * \\
(0.078)\end{array}$ & & $\begin{array}{l}0.173^{*} \\
(0.094)\end{array}$ & \\
\hline $\begin{array}{l}\text { Any corruption involving President } \\
\text { (dummy variable) }\end{array}$ & & $\begin{array}{l}0.603 * * * \\
(0.205)\end{array}$ & & $\begin{array}{l}0.458^{*} \\
(0.253)\end{array}$ \\
\hline Education (years) & $\begin{array}{l}0.043^{*} \\
(0.024)\end{array}$ & $\begin{array}{l}0.044^{*} \\
(0.024)\end{array}$ & $\begin{array}{l}0.083^{* *} \\
(0.034)\end{array}$ & $\begin{array}{l}0.087 * * * \\
(0.033)\end{array}$ \\
\hline Age & $\begin{array}{l}0.019 * * * \\
(0.007)\end{array}$ & $\begin{array}{l}0.019 * * * \\
(0.007)\end{array}$ & $\begin{array}{l}0.021 * * \\
(0.008)\end{array}$ & $\begin{array}{l}0.021 * * \\
(0.009)\end{array}$ \\
\hline Female & $\begin{array}{l}-0.185 \\
(0.164)\end{array}$ & $\begin{array}{l}-0.183 \\
(0.163)\end{array}$ & $\begin{array}{l}-0.678^{* * *} \\
(0.235)\end{array}$ & $\begin{array}{l}-0.683^{* * *} \\
(0.234)\end{array}$ \\
\hline Predicted per-capita consumption & $\begin{array}{l}0.406 \\
(0.255)\end{array}$ & $\begin{array}{l}0.339 \\
(0.257)\end{array}$ & $\begin{array}{l}0.284 \\
(0.333)\end{array}$ & $\begin{array}{l}0.220 \\
(0.334)\end{array}$ \\
\hline Participation in social activities & $\begin{array}{l}0.002 \\
(0.008)\end{array}$ & $\begin{array}{l}0.001 \\
(0.008)\end{array}$ & $\begin{array}{l}-0.020^{*} \\
(0.011)\end{array}$ & $\begin{array}{l}-0.020^{*} \\
(0.010)\end{array}$ \\
\hline $\begin{array}{l}\text { Participation in social activities where } \\
\text { road project likely discussed }\end{array}$ & $\begin{array}{l}0.046 \\
(0.034)\end{array}$ & $\begin{array}{l}0.050 \\
(0.035)\end{array}$ & $\begin{array}{l}0.114 * * * \\
(0.042)\end{array}$ & $\begin{array}{l}0.116^{* * *} \\
(0.041)\end{array}$ \\
\hline Lives in project hamlet & $\begin{array}{l}0.674 * * * \\
(0.169)\end{array}$ & $\begin{array}{l}0.671^{* * *} \\
(0.167)\end{array}$ & $\begin{array}{l}0.959 * * * \\
(0.216)\end{array}$ & $\begin{array}{l}0.943 * * * \\
(0.215)\end{array}$ \\
\hline Family member of village government & $\begin{array}{l}0.258^{*} \\
(0.155)\end{array}$ & $\begin{array}{l}0.271^{*} \\
(0.157)\end{array}$ & $\begin{array}{l}0.586^{* * *} \\
(0.208)\end{array}$ & $\begin{array}{l}0.599 * * * \\
(0.209)\end{array}$ \\
\hline Family member of project leader & $\begin{array}{l}-0.186 \\
(0.222)\end{array}$ & $\begin{array}{l}-0.186 \\
(0.219)\end{array}$ & $\begin{array}{l}0.007 \\
(0.343)\end{array}$ & $\begin{array}{l}-0.009 \\
(0.341)\end{array}$ \\
\hline Version B of survey form & $\begin{array}{l}0.135 \\
(0.169)\end{array}$ & $\begin{array}{l}0.124 \\
(0.170)\end{array}$ & $\begin{array}{l}0.019 \\
(0.025)\end{array}$ & $\begin{array}{l}0.019 \\
(0.025)\end{array}$ \\
\hline Sample controls & Yes & Yes & Yes & Yes \\
\hline Observations & 1249 & 1249 & 829 & 829 \\
\hline Fixed effects & Village & Village & Village & Village \\
\hline
\end{tabular}

Notes: See notes to Table 6. All specifications are conditional logit models, where the village is the conditioning variable. Coefficient estimates are expressed as log odd ratios. Robust standard errors in parentheses. Note that the sample size is lower in columns ( 3 ) and (4) as, in the conditional logit specification, all villages where there is no variation in the dependent variable are automatically dropped from model.

This section examines empirically whether aggregate biases are substantial enough to affect qualitative conclusions about the correlates of corruption. In doing this, it is important to note that I do not necessarily claim a causal interpretation of the relationship between these variables and corruption; rather, the main question of interest is the consistency of the partial correlations between these variables and corruption across the various ways of measuring corruption.

To examine aggregate biases, I estimate the following two regressions via OLS:

$\tilde{c}_{v}=\alpha_{1}+Z_{v}^{\prime} \alpha_{2}+v_{v}$

$\tilde{P}_{v h}=\beta_{1}+Z_{v}^{\prime} \beta_{2}+X_{v h}^{\prime} \beta_{3}+v_{v}^{\prime}$

and examine the similarity or difference between the coefficients $\alpha_{2}$ and $\beta_{2}$, which capture the impact of village characteristics $Z$ on missing expenditures and perceived corruption, respectively. To obtain the most comparable possible coefficients across these very different measures, I normalize all of the corruption measures to have mean 0 and standard deviation 1 , so that all coefficients can be interpreted in terms of standard deviation changes in the corruption measure. I denote the normalized versions of missing expenditures by $\tilde{c}_{v}$ and the normalized version of perceptions by $\tilde{P}_{v h .}{ }^{22}$ That being said,

\footnotetext{
22 For the categorical-response perceptions variable, I impose a linear scale on the variable, and then normalize this linearized variable to have mean 0 and standard deviation 1. Although this imposes a linearized form on categorical response variable, as discussed in Footnote 1 above, in other specifications OLS regressions using this linearized variable produce qualitatively similar results to the ordered probit specifications, which suggests that the linear assumptions are not substantially affecting the results. I have also considered ordered probit and probit versions of Eq. (4), and they produce qualitatively similar results to those in Table 9 below. Similarly, for the binary dependent variable, I normalize the variable to have mean 0 and standard deviation 1.
} 
Table 9

Village-level differences.

\begin{tabular}{|c|c|c|c|c|c|c|c|}
\hline & \multirow{2}{*}{$\begin{array}{l}\text { Missing } \\
\text { expenditures }\end{array}$} & $(2)$ & $(3)$ & \multirow{2}{*}{\multicolumn{2}{|c|}{$\begin{array}{l}\text { (4) } \\
\text { Any likelihood of corruption } \\
\text { in road project (dummy } \\
\text { variable, Std Dev 1) }\end{array}$}} & \multirow{2}{*}{\multicolumn{2}{|c|}{$\begin{array}{l}(6) \\
\text { Trust other villagers (dummy } \\
\text { variable, Std Dev } 1 \text { ) }\end{array}$}} \\
\hline & & \multicolumn{2}{|c|}{$\begin{array}{l}\text { Likelihood of corruption in } \\
\text { road project (linear scale, } \\
\text { Std Dev } 1 \text { ) }\end{array}$} & & & & \\
\hline \multicolumn{8}{|l|}{ Demographics } \\
\hline Log population & $\begin{array}{l}0.263 * * \\
(0.112)\end{array}$ & $\begin{array}{l}0.176^{* * *} \\
(0.061)\end{array}$ & $\begin{array}{l}0.129 * * \\
(0.055)\end{array}$ & $\begin{array}{l}0.175^{* * * *} \\
(0.058)\end{array}$ & $\begin{array}{l}0.119 * * \\
(0.051)\end{array}$ & $\begin{array}{l}-0.142^{*} \\
(0.076)\end{array}$ & $\begin{array}{l}-0.156^{* *} \\
(0.075)\end{array}$ \\
\hline Mean village education level (years) & $\begin{array}{l}-0.040 \\
(0.047)\end{array}$ & $\begin{array}{c}-0.052 \\
(0.032)\end{array}$ & $\begin{array}{l}-0.021 \\
(0.031)\end{array}$ & $\begin{array}{l}-0.049 \\
(0.034)\end{array}$ & $\begin{array}{l}-0.007 \\
(0.033)\end{array}$ & $\begin{array}{l}-0.010 \\
(0.041)\end{array}$ & $\begin{array}{l}-0.024 \\
(0.043)\end{array}$ \\
\hline Share of population poor & $\begin{array}{l}-0.335 \\
(0.252)\end{array}$ & $\begin{array}{l}-0.143 \\
(0.165)\end{array}$ & $\begin{array}{l}-0.123 \\
(0.133)\end{array}$ & $\begin{array}{l}-0.113 \\
(0.159)\end{array}$ & $\begin{array}{l}-0.062 \\
(0.140)\end{array}$ & $\begin{array}{l}0.406^{* *} \\
(0.191)\end{array}$ & $\begin{array}{l}0.437 * * \\
(0.191)\end{array}$ \\
\hline \multicolumn{8}{|l|}{ Social characteristics } \\
\hline Ethnic fragmentation & $\begin{array}{l}-1.449 * * \\
(0.568)\end{array}$ & $\begin{array}{l}1.721^{* * *} \\
(0.322)\end{array}$ & $\begin{array}{l}1.297 * * * \\
(0.293)\end{array}$ & $\begin{array}{l}1.928^{* * *} \\
(0.340)\end{array}$ & $\begin{array}{l}1.467 * * * \\
(0.332)\end{array}$ & $\begin{array}{l}-1.082^{*} \\
(0.593)\end{array}$ & $\begin{array}{l}-0.929 \\
(0.651)\end{array}$ \\
\hline Religious fragmentation & $\begin{array}{l}-1.350 \\
(1.089)\end{array}$ & $\begin{array}{l}0.082 \\
(0.734)\end{array}$ & $\begin{array}{c}-0.318 \\
(0.705)\end{array}$ & $\begin{array}{l}0.092 \\
(0.721)\end{array}$ & $\begin{array}{c}-0.301 \\
(0.700)\end{array}$ & $\begin{array}{l}-1.031 \\
(0.756)\end{array}$ & $\begin{array}{c}-0.822 \\
(0.755)\end{array}$ \\
\hline Intensity of social participation & $\begin{array}{l}0.024 \\
(0.064)\end{array}$ & $\begin{array}{l}-0.054^{*} \\
(0.029)\end{array}$ & $\begin{array}{l}-0.041 \\
(0.025)\end{array}$ & $\begin{array}{l}-0.073^{* *} \\
(0.029)\end{array}$ & $\begin{array}{l}-0.063^{* *} \\
(0.026)\end{array}$ & $\begin{array}{l}0.084^{* *} \\
(0.042)\end{array}$ & $\begin{array}{l}0.077^{*} \\
(0.043)\end{array}$ \\
\hline \multicolumn{8}{|l|}{ Transparency } \\
\hline Meetings with written accountability report & $\begin{array}{l}-0.243 \\
(0.155)\end{array}$ & $\begin{array}{c}-0.021 \\
(0.093)\end{array}$ & $\begin{array}{l}-0.007 \\
(0.074)\end{array}$ & $\begin{array}{c}-0.077 \\
(0.089)\end{array}$ & $\begin{array}{c}-0.082 \\
(0.076)\end{array}$ & $\begin{array}{l}-0.231^{* *} \\
(0.114)\end{array}$ & $\begin{array}{l}-0.232^{* *} \\
(0.113)\end{array}$ \\
\hline Number of ordinances from village parliament & $\begin{array}{l}-0.019 \\
(0.017)\end{array}$ & $\begin{array}{l}0.007 \\
(0.012)\end{array}$ & $\begin{array}{l}0.015 \\
(0.009)\end{array}$ & $\begin{array}{l}0.012 \\
(0.011)\end{array}$ & $\begin{array}{l}0.015 \\
(0.010)\end{array}$ & $\begin{array}{l}0.006 \\
(0.013)\end{array}$ & $\begin{array}{l}0.007 \\
(0.013)\end{array}$ \\
\hline \multicolumn{8}{|l|}{ Experimental interventions } \\
\hline Audit treatment & $\begin{array}{l}-0.302 * * \\
(0.130)\end{array}$ & $\begin{array}{c}-0.053 \\
(0.088)\end{array}$ & $\begin{array}{l}-0.125^{*} \\
(0.070)\end{array}$ & $\begin{array}{l}-0.028 \\
(0.087)\end{array}$ & $\begin{array}{l}-0.064 \\
(0.072)\end{array}$ & $\begin{array}{l}-0.179 \\
(0.115)\end{array}$ & $\begin{array}{l}-0.152 \\
(0.118)\end{array}$ \\
\hline Invitations treatment & $\begin{array}{l}-0.030 \\
(0.106)\end{array}$ & $\begin{array}{l}0.024 \\
(0.077)\end{array}$ & $\begin{array}{l}0.026 \\
(0.068)\end{array}$ & $\begin{array}{c}-0.006 \\
(0.069)\end{array}$ & $\begin{array}{l}0.023 \\
(0.064)\end{array}$ & $\begin{array}{c}-0.054 \\
(0.069)\end{array}$ & $\begin{array}{l}-0.054 \\
(0.070)\end{array}$ \\
\hline Invitations + comment treatment & $\begin{array}{l}-0.022 \\
(0.094)\end{array}$ & $\begin{array}{l}0.161^{*} \\
(0.089)\end{array}$ & $\begin{array}{l}0.121 \\
(0.073)\end{array}$ & $\begin{array}{l}0.108 \\
(0.088)\end{array}$ & $\begin{array}{l}0.095 \\
(0.077)\end{array}$ & $\begin{array}{l}0.091 \\
(0.082)\end{array}$ & $\begin{array}{l}0.123 \\
(0.084)\end{array}$ \\
\hline \multicolumn{8}{|l|}{ Corruption perceptions of } \\
\hline President & $\mathrm{N} / \mathrm{A}$ & No & Yes & No & Yes & No & Yes \\
\hline Subdistrict official & $\mathrm{N} / \mathrm{A}$ & No & Yes & No & Yes & No & Yes \\
\hline Village head & $\mathrm{N} / \mathrm{A}$ & No & Yes & No & Yes & No & Yes \\
\hline Village parliament & $\mathrm{N} / \mathrm{A}$ & No & Yes & No & Yes & No & Yes \\
\hline Respondent covariates & $\mathrm{N} / \mathrm{A}$ & No & Yes & No & Yes & No & Yes \\
\hline Sample controls & $\mathrm{N} / \mathrm{A}$ & Yes & Yes & Yes & Yes & Yes & Yes \\
\hline Observations & 443 & 3056 & 2716 & 3366 & 2996 & 3302 & 2954 \\
\hline$R$-squared & 0.06 & 0.06 & 0.23 & 0.06 & 0.17 & 0.05 & 0.05 \\
\hline
\end{tabular}

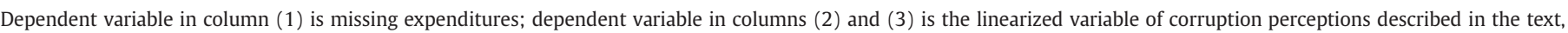

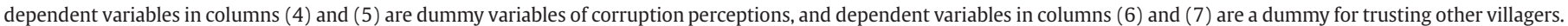



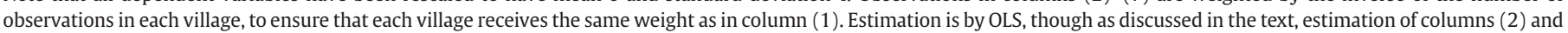

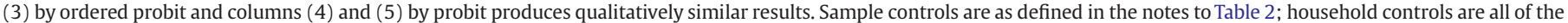

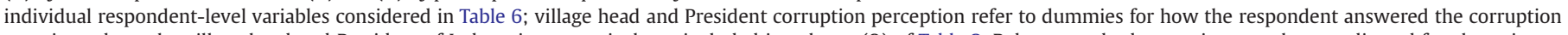

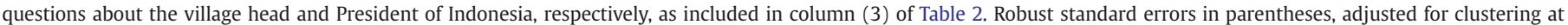
subdistrict level.*Significant at $10 \%$; **Significant at $5 \%$; ***Significant at $1 \%$.

I will focus primarily on those results for which the estimated coefficients $\alpha_{2}$ and $\beta_{2}$ are of different sign, not just of different magnitude, so as not to rely too heavily on this normalization. ${ }^{23}$

\footnotetext{
23 An alternative, equivalent approach which does not rely on these normalizations is as follows. Suppose the true model of the world is:

$c_{v}=\alpha_{1}+Z_{v}^{\prime} \alpha_{2}+\varepsilon_{v}$

$B_{v h}=\tilde{\beta}_{1}+Z_{v}^{\prime} \tilde{\beta}_{2}+X_{v h}^{\prime} \tilde{\beta}_{3}+\tilde{\beta}_{4} c_{v}+\tilde{v}_{v}^{\prime}$.

The coefficient of interest is $\alpha_{2}$, the effect of village characteristics $Z$ on real corruption levels. In most circumstances, $c$ is unobserved. If we assume that $\tilde{\beta}_{2}=0$ (i.e., $Z_{v}$ affects $B_{v h}$ only through its effect on $c_{v}$ ), then the estimated coefficient $\beta_{2}$ in Eq. (4) in the text will be equal to $\alpha_{2}$, the coefficient of interest. In the setting here, we also observe $c$, so we can estimate Eq. (6) directly and test whether $\tilde{\beta}_{2}=0-$ i.e., we can test directly whether $Z$ has no direct effect on perceptions other than through its effect on the percent missing. This is equivalent to testing whether $\alpha_{2}=\beta_{2}$ in Eqs. (3) and (4) in the text. Estimating Eq. (6) and testing whether $\tilde{\beta}_{2}=0$ yields similar results to those presented in Table 9 and discussed below. In particular, the coefficients $\tilde{\beta}_{2}$ in Eq. (6) are statistically significantly different from 0 for the mean village education level, ordinances from village parliament, social participation, and village ethnic fragmentation.
}

The results are presented in Table 9. Column (1) presents the results when missing expenditures is the dependent variable, columns (2) and (3) present the result when the scaled linear version of perceptions is the dependent variable, and columns (4) and (5) present the results when the scaled dummy version of perceptions is the dependent variable. Columns (2) and (4) do not include the controls for corruption perceptions of the President, the village head, etc. or the respondentlevel characteristics included in Table 6; columns (3) and (5) do.

The results suggest that for identifying the effects of basic demographic characteristics, such as population and education, the results from perceptions (columns 2-5) appear to give similar results to the more objective missing expenditures measure (column 1). But when considering characteristics related to trust - such as ethnic heterogeneity and social participation - examining the impact on corruption perceptions rather than actual corruption may lead to biased conclusions.

Of particular note are the estimates on ethnic heterogeneity. The cross-country corruption literature has found that heterogeneity is positively associated with corruption perceptions (e.g., Mauro, 1995; LaPorta et al., 1999). Following the standard approach in the literature, I construct as a measure of ethnic and religious heterogeneity the probability that 
two randomly drawn individuals are from different ethnic or religious groups, respectively. ${ }^{24}$ Consistent with the literature, I find that ethnic heterogeneity is associated with greater perceived levels of corruption. Specifically, moving from a village with no ethnic heterogeneity to a village with the maximum ethnic heterogeneity in the sample (0.51) is associated with an increase of between 0.65 and 1 standard deviations in the perceived corruption measure, equivalent to an increase of about 50 percentage points in the probability of reporting positive corruption in the project. ${ }^{25}$ However, when I examine the relationship between ethnic heterogeneity and the missing expenditures measure, I get the opposite result - moving from a village with no ethnic heterogeneity to a village with the maximum ethnic heterogeneity in the sample is associated with a decrease in the percent missing variable of about 0.73 standard deviations. The coefficients on religious fragmentation show a similar pattern $-\mathrm{a}$ large negative coefficient when missing expenditures is the dependent variable, and coefficients much closer to zero (and in some cases positive) when perceptions are the dependent variable - though the results on religious heterogeneity are not statistically significant.

One possible explanation for these differences is, much as respondents who believe the President of Indonesia is more likely to be corrupt are more likely to go to monitoring meetings (see Section 4.2 above), ethnic heterogeneity lowers the level of trust in the village resulting in higher perceived levels of corruption, more monitoring, and lower actual corruption. In fact, there is suggestive evidence consistent with this explanation. The household survey asked respondents a version of the World Values Survey trust question, in which respondents were asked about the degree to which they trust other residents of the village. ${ }^{26}$ On average, $52 \%$ of residents in villages with ethnic heterogeneity less than 0.05 reported trusting their fellow villagers, whereas only $36 \%$ of residents in villages with ethnic heterogeneity greater than 0.05 reported trusting their fellow co-residents.

To examine this relationship more systematically, columns (6) and (7) of Table 9 regress trusting other villagers on the same set of village characteristics used before. The results (which are expressed as standard deviations to be comparable to other rows in the tables) show that the negative relationship between ethnic heterogeneity and trust is statistically significant (column 6), though it attenuates very slightly when we also include individual respondent covariates (column 7). Moreover, in high ethnic heterogeneity villages (defined similarly using the 0.05 threshold), the number of people who attend accountability meetings was $22 \%$ higher than in villages with low ethnic heterogeneity. ${ }^{27}$ These findings provide suggestive evidence that lower levels of trust correlated with ethnic heterogeneity lead to more negative corruption perceptions, which in turn lead to higher levels of monitoring, lowering actual corruption levels. ${ }^{28}$

\footnotetext{
${ }^{24}$ Overall, the sample is relatively homogeneous - the probability that two individuals in the same village are from different ethnic groups is greater than 0.05 in only $9 \%$ of villages, and the probability that two individuals in the same village are from different religious groups is greater than 0.05 in only $10 \%$ of villages. In results not reported in the table, I have verified that the results are qualitatively similar if I remove outliers in the ethnic heterogeneity variable.

${ }^{25}$ Moreover, controlling for the overall heterogeneity in the village, those respondents whose ethnic group differed from that of the village head were 12 percentage points more likely to report positive probability of corruption in the project (results not shown).

${ }^{26}$ Specifically, they were asked: "In general, do you think that other residents of the village can be trusted, or you have to be careful in dealing with them?" The variable is coded 1 if the respondents say they can trust other residents of the village, and 0 if they say they have to be careful in dealing with them.

${ }^{27}$ This difference is statistically significant at the $1 \%$ level. The point estimates are virtually identical if the village-level characteristics included in Table 9 are included as well (except, obviously, ethnic heterogeneity). Using a linear ethnic heterogeneity measure, rather than the discrete cutoff for ethnic heterogeneity greater than 0.05 , gives very similar results.

28 This feedback mechanism may also explain the difference between the result in this paper that ethnic heterogeneity leads to less corruption and results elsewhere. For example, the rice program studied in Olken (2006a) had no participatory monitoring mechanism, so the feedback mechanism postulated here between ethnic heterogeneity, increased monitoring, and less corruption would not have occurred in the case of the rice program.
}

A similar effect to ethnic heterogeneity - though in the opposite direction - can be seen by looking at the social participation variables. I define the intensity of social participation as the average number of times an adult in the village participated in a social group of any kind in the past 3 months. This measure is obtained from a census of social groups obtained from the head of each hamlet. As can be seen in Table 9, increased participation in social groups in the village is associated with a decrease in perceived corruption levels. This is consistent with the results reported by Putnam et al. (1993). But when we look at the actual corruption level, we find, if anything, that increased social participation is associated with higher measured corruption levels, though the point estimate is statistically insignificant. Similar, though weaker, differences between the perceptions variable and missing expenditures appear when we consider a measure of whether there is a political opposition in the village that could potentially monitor the project - the degree of activeness of the village parliament, or BPD. ${ }^{29}$

\subsection{Using perceptions to detect experimental impacts}

Given the difficulties in measuring corruption directly, an important question is the degree to which perceptions data can substitute for more direct measures of corruption in cases where the latter is difficult or infeasible to collect. To examine this, Table 9 also examines how the experimental results reported in Olken (2007) would have differed had the perceptions-based measure been used to evaluate corruption instead of the missing expenditures measure. As described above, there were three experimental interventions in these villages - an audit treatment, in which villages were told in advance that they would be audited by the central government audit agency with probability 1 , an invitations treatment, where hundreds of written invitations were passed out to villagers to attend accountability meetings, and an anonymous comment form treatment, where villagers were able to give comments about the project without fear of retaliation.

As can be seen in column (1) of Table 9, the audit intervention was associated with a statistically significant reduction in missing expenditures of about 0.3 standard deviations, whereas the invitations and invitations plus comment forms treatments were associated with a very small, and statistically insignificant, reduction in the missing expenditures variable. By contrast, when examining the perceptions variable, the audit treatment has a much smaller (and in most specifications not statistically significant) effect, and the invitations and invitations plus comment form treatments are associated with increases in the perceptions of corruption, in some cases statistically significantly so. The conclusions from the study would therefore have been quite different had perceptions been the main measure of corruption, rather than missing expenditures.

In this particular case, we can speculate as to some of the specific reasons why perceptions and actual corruption would respond differently to the experimental treatments. For example, as reported in Olken (2007), the audits primarily resulted in a reduction in missing quantities, whereas the results in Table 4 show that villagers are much better at detecting inflated prices. Villagers' perceptions of corruption do not detect precisely the type of corruption where the experiments had the greatest impact. Also, one can also easily imagine that anonymous comment forms would increase people's perceptions of corruption by providing information about corruption, while in fact having the opposite effect on actual corruption levels. More generally, the difference in the results between the two types of measures highlights the importance of obtaining unbiased, direct measures of corruption.

\footnotetext{
29 To measure how active the BPD was, I examine the number of ordinances the BPD had issued in the previous year. Though the BPD coefficients are not separately significant in either the missing expenditures or perceptions regressions, the difference between them appears to be statistically significant using the method discussed in Footnote 5. I also consider another measure of transparency in the project - whether a written report of project expenses was provided at a village accountability meeting - though the results are not conclusive in either direction.
} 


\section{Conclusion}

This paper has examined the relationship between perceptions of corruption and a more objective measure of corruption, in the context of a road-building program in rural Indonesia. The paper shows empirically that villagers' perceptions of corruption do appear to be positively (though weakly) correlated with the more objective missing expenditures measure. Moreover, villagers appear to be able to distinguish between the overall probability of corruption in the village and corruption specific to the road project.

Despite this, the magnitude of the correlation between reported corruption perceptions and missing expenditures is small. In part, this may be because, on average, almost all of the corruption in the project was hidden by inflating quantities, which are hard for villagers to detect, rather than marking up prices, which are easier for villagers to detect. This suggests an important feedback mechanism between transparency - which increases the ability of citizens to detect corruption - and corruption levels. It also suggests that, at least in this case, villagers do not currently possess enough capability to detect corruption to effectively monitor local officials, at least without additional external help.

I then examine the extent of biases in corruption perceptions. The results show that there are significant individual-level biases in how respondents answer the corruption question. Moreover, there is evidence that for some village-level characteristics, particularly those associated with levels of trust, such as ethnic heterogeneity and social participation, using perceptions to measure corruption can produce very different answers from the results obtained using a more objective measure of corruption. I present suggestive evidence in favor of the idea that biases in individual's views about corruption can lead to increased monitoring behavior, which may in turn reduce corruption. These results suggest that perceptions data should be used for empirical research on the determinants of corruption with considerable caution, and that there is little alternative to continuing to collect more objective measures of corruption, difficult though that may be.

\section{Appendix A. Data details}

The original data was collected in 608 total villages. The sample in this paper, however, is limited to the 477 villages where the missing expenditures variable, described above, could be constructed. The missing expenditures variable could not be calculated in some villages for one of four reasons: (1) surveyor error in locating the road, (2) the project consisted largely of a partial rehabilitation of an existing road, (3) agglomerated expenditures reports (i.e., the village expenditure report combined expenditures in the road project with other projects that could not be independently measured, such as a school), or (4) villages that had asphalted the road that refused to let the engineers break the asphalt to conduct the engineering survey.

The household survey was designed as a stratified random sample, containing between six and thirteen respondents per village, selected as follows. Two respondents were selected from the hamlets in which the road was located by first randomly selecting a hamlet, and then randomly selecting a neighborhood (RT) in that hamlet. A complete list of households in the RT was obtained from the neighborhood head, and two households were drawn randomly from that list. Individual respondents were drawn from a list of all adults age 18 or over in the selected households. Two additional respondents were selected from the hamlets in which the road was not being built using the same procedure. As men in the village tend to participate much more in road construction activities, the randomization was designed such that, of the four respondents selected in this manner, three were men and one was a woman. In villages receiving the Comment Form treatment, an additional four respondents were drawn using the same procedure, two from hamlets with the project and two from hamlets that did not contain the project. In each village, two additional respondents were drawn randomly from the attendance list of Village Meeting II, which was held before the randomization was announced, and is therefore exogenous with respect to the experiments. Finally, in some Comment Form villages an additional 3 respondents were added, randomly selected from the two neighborhoods above (the reasons for this will be discussed below). Each respondent received compensation of Rp. 10,000 (\$1.20), equal to slightly more than half of the typical daily agricultural wage in the study area.

Given this sample selection, a natural question is whether the sample should be re-weighted to reflect the fact that different respondents had different probabilities of being sampled. As is apparent from the description of the sampling, women were systematically undersampled, and those who attended a pre-randomization village meeting were systematically oversampled. In all specifications, I control for how the respondent was sampled (i.e., whether the respondent was from a hamlet with or without the road project, whether the respondent was selected from the attendance list at Village Meeting II, and whether the household was one of the 3 additional households added in the Comment Form villages). The question is whether, given these control for level differences among these samples, one needs to reweight to account for treatment effect heterogeneity in the relationship between missing expenditures and perceptions. As discussed by Deaton (1995), weighting the sample makes the point estimates invariant to survey design, but reduces the effective power and, in the presence of treatment heterogeneity, does necessarily obtain consistent estimates for the true average population effect. Accordingly, the results presented below in the text are unweighted. Using sample weights in the regressions that account for the differential probability of sampling and which weight each village equally (i.e., so that comment form villages are not over-weighted in the regression) does not substantively change the results, but not surprisingly it does reduce the statistical significance of the missing expenditures variable in columns (2) and (3) of Table 2.

As discussed above, beyond simply measuring perceptions, an additional goal of the survey was to measure how stated perceptions about corruption change when respondents know that their answers will be used for monitoring. To examine this, after all corruption questions except for questions involving corruption in the road project had been asked, a randomly selected subset of respondents in the Comment Form villages were told that their responses to the questions about corruption in the project would be used, anonymously, as part of the overall report on the comment forms presented at the accountability meeting (the Form B treatment discussed above). Due to a training error, approximately $60 \%$ of enumerators appear to have given Form B surveys to all households in Comment Form villages. In the Form B experiment discussed above, I restrict attention to those villages where the experiment was carried out properly. Moreover, in approximately half of all Comment Form villages, three additional households were surveyed, drawn randomly from the same neighborhoods as before, two of whom received Form A and one of whom received Form B. In all specifications I include a dummy variable for which version of the form each household received in all specifications, as well as dummies for whether the household was sampled as part of this additional three households per village, in addition to dummies for which experimental treatment the village was assigned (i.e. comment forms, invitations, or audits). Although I include these dummies in all specifications in this paper, doing so does not substantially affect the results.

In addition to the corruption question, the household survey included a wide variety of other covariates, such as a household roster, education levels, participation in social activities and in the road project, assets, and family relationships to various village officials. To estimate household expenditure of respondents, I used the 1999 SSD (Hundred Villages Survey), an Indonesian statistics bureau dataset, containing 3193 rural Javanese households. The SSD asked both a detailed expenditure questionnaire and the same set of asset 
questions used in my household survey. In the SSD, I used OLS to estimate the relationship between log household expenditure and the following variables, all of which I observe in my survey: log household size, whether the household was headed by a woman, the percentage of household members consisting of children ages $0-3,4-6,7-9,10-$ 12 , and 13-16, dummies for whether the household has a stove, refrigerator, radio, television, satellite dish, motorbike, car, and electricity, dummies for floor type, wall type, and ceiling type, the total amount of land held by the household, whether the household consumes meat at least once a week, whether each household member has at least two sets of clothes, whether the household uses modern medicine when a child is sick. I then used the estimated coefficients from the SSD to predict household expenditure in my survey. Combined, these 34 variables have an $R$-squared of 0.58 predicting log household expenditure in the SSD, which suggests that predicted expenditure is a reasonable approximation for actual expenditure, at least for the purposes used here.

\section{References}

Azfar, Omar, Murrell, Peter, "Identifying reticent respondents: Assessing the quality of survey data on corruption and values," mimeo, University of Maryland, 2005.

Bassett, William F., Lumsdaine, Robin L., "Outlook, Outcomes, and Optimism," mimeo, Brown University, 1999.

Bassett, William F., Lumsdaine, Robin L., 2001. Probability limits: are subjective assessments adequately accurate? Journal of Human Resources 36 (2), 327-363 Spring.

Beaman, Lori, Chattopadhyay, Raghabendra, Pande, Esther Duflo Rohini, and Topalova, Petia, "Powerful Women: Does Exposure Reduce Bias?" Unappreciated Service: Performance, Perceptions, and Women Leaders in India," mimeo, MIT, July 2008.

Bernheim, B. Douglas, 1989. The timing of retirement: a comparison of expectations and realizations. In: Wise, David (Ed.), The Economics of Aging. University of Chicago Press, Chicago, pp. 259-283.

Bertrand, Marianne, Mullainathan, Sendhil, 2001. Do people mean what they say? Implications for subjective survey data. American Economic Review 91 (2), 67-72 May.

Bertrand, Marianne, Djankov, Simeon, Hanna, Rema, Mullainathan, Sendhil, 2006. Does corruption produce unsafe drivers? NBER Working Paper \#12274.

Deaton, Angus, 1995. Data and econometric tools for development analysis. In: Behrman, Jere, Srinivasan, T.N. (Eds.), Handbook of Development Economics, vol. 3. North Holland, New York, pp. 1785-1882.

Di Tella, Rafael, Schargrodsky, Ernesto, 2003. The role of wages and auditing during a crackdown on corruption in the city of Buenos Aires. Journal of Law and Economics 46 April.

Dominitz, Jeffrey, Manski, Charles, 1997. Using expectations data to study subjective income expectations. Journal of the American Statistical Association 92 (439), 855-862.
Fisman, Raymond, Wei, Shang-Jin, 2004. Tax rates and tax evasion: evidence from 'missing imports' in China. Journal of Political Economy 112 (2), 471-500.

Gray-Molina, George, Pérez de Rada, Ernesto, Yeñez, Ernesto, 2001. Does voice matter? Participation and controlling corruption in Bolivian hospitals. In: Tella, Rafael Di, Savedoff, WIlliam D. (Eds.), Diagnosis Coruption. IADB Press, Washington.

Hsieh, Chang-Tai, Moretti, Enrico, 2006. Did Iraq cheat the United Nations? Underpricing, bribes, and the oil for food program. Quarterly Journal of Economics 121 (4), 1211-1248 Decmber.

Hurd, Michael D., McGarry, Kathleen, 1995. Evaluation of the subjective probabilities of survival in the health and retirement study. Journal of Human Resources 30, S268-S292.

Hurd, Michael D., McGarry, Kathleen, 2002. The predictive validity of subjective probabilities of survival. Economic Journal 112, 966-985 October.

Jacob, Brian, Lefgren, Lars, 2005. Principals as agents: subjective performance assessment in education. NBER Working Paper \#11463.

Kaufmann, Daniel, Kraay, Aart, Mastruzzi, Massimo, "Governance Matters IV: Governance Indicators for 1996-2004,” mimeo, World Bank, May 2005.

King, Gary, Murray, Christopher J.L., Salomon, Joshua A., Tandon, Ajay, 2004. Enhancing the validity and cross-cultural comparability of survey research. American Political Science Review 98 (1), 191-207 February.

Knack, Stephen, Keefer, Philip, 1995. Institutions and economic performance: crosscountry tests using alternative institutional measures. Economics \& Politics 7 (3) 207-227.

Krueger, Anne O., 1974. The political economy of the rent-seeking society. American Economic Review 64 (3), 291-303 June.

LaPorta, Raphael, Lopez-de-Silanes, Florencio, Shleifer, Andrei, Vishny, Robert, 1999. The quality of government. Journal of Law, Economics, and Organizations 15 (1), 222-279.

Lambsdorff, Johann G., "Background Paper to the 2003 Corruption Perceptions Index," mimeo: Transparency International, September 2003.

Mauro, Paulo, 1995. Corruption and growth. Quarterly Journal of Economics 110 (3), 681-712 August.

Mocan, Naci, 2004. What determines corruption? International evidence from micro data. NBER Working Paper \#10460. May.

Olken, Benjamin A., 2006a. Corruption and the cost of redistribution. Journal of Public Economics 90 (4-5), 853-870 May.

Olken, Benjamin A., 2006b. Corruption perceptions vs. corruption reality. NBER Working Paper \#12428. July.

Olken, Benjamin A., 2007. Monitoring corruption: evidence from a field experiment in Indonesia. Journal of Political Economy 115 (2), 200-249 April.

Putnam, Robert D., Leonardi, Robert, Nanetti, Raffaella Y., 1993. Making Democracy Work: Civic Traditions in Modern Italy. Princeton University Press, Princeton.

Reinikka, Ritva, Svensson, Jakob, 2004. Local capture: evidence from a central government transfer program in Uganda. Quarterly Journal of Economics 119 (2) 679-706 May.

Rose-Ackerman, Susan, "The Challenge of Poor Governance and Corruption," mimeo, Copenhagen Consensus and Yale University, 2004.

Shleifer, Andrei, Vishny, Robert W., 1993. Corruption. Quarterly Journal of Economics 108 (3), 599-617 August.

Treisman, Daniel, 2000. The causes of corruption: a cross-national study. Journal of Public Economics 76, 399-457.

Yang, Dean, "Can Enforcement Backfire? Crime Displacement in the Context of a Common Customs Reform," University of Michigan, mimeo, 2004. 